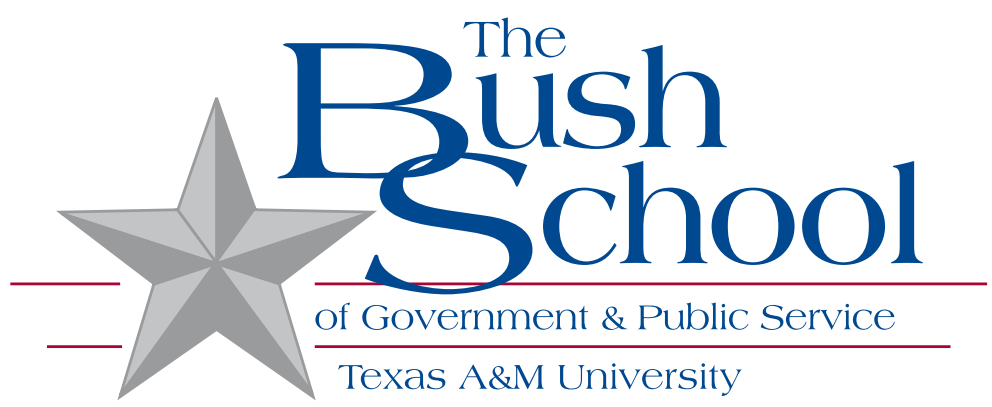

\title{
INSIDER TRADING AND THE VALUATION OF INTERNATIONAL STRATEGIC ALLIANCES IN EMERGING STOCK MARKETS
}

\author{
Stewart R. Miller* \\ The University of Texas at Austin \\ Austin, TX 78712-1174 \\ stewart.miller@mccombs.utexas.edu \\ Dan Li \\ Texas A \& M University \\ College Station, Texas 77843-4221 \\ dli@mays.tamu.edu \\ Lorraine Eden \\ Texas A \& M University \\ College Station, Texas 77843-4221 \\ leden@mays.tamu.edu \\ Michael Hitt \\ Texas A \& M University \\ College Station, Texas 77843-4221 \\ mhitt@mays.tamu.edu \\ * Corresponding author
}

Bush School Working Paper \# 579

No part of the Bush School transmission may be copied, downloaded, stored, further transmitted, transferred, distributed, altered, or otherwise used, in any form or by any means, except: (1) one stored copy for personal use, non-commercial use, or (2) prior written consent. No alterations of the transmission or removal of copyright notices is permitted. 


\title{
INSIDER TRADING AND THE VALUATION
}

\section{OF INTERNATIONAL STRATEGIC ALLIANCES IN EMERGING STOCK MARKETS}

\author{
Stewart R. Miller* \\ The University of Texas at Austin \\ Austin, TX 78712-1174 \\ Phone: 512-471-5277 \\ Fax: 512-471-3937 \\ E-mail: stewart.miller@mccombs.utexas.edu \\ Dan Li \\ Texas A \& M University \\ College Station, Texas 77843-4221 \\ Phone: 979-845-0926 \\ Fax: 979-845-9641 \\ E-mail: dli@mays.tamu.edu \\ Lorraine Eden \\ Texas A \& M University \\ College Station, Texas 77843-4221 \\ Phone: 979-862-4053 \\ Fax: 979-845-9641 \\ E-Mail: leden@mays.tamu.edu \\ Michael Hitt \\ Texas A \& M University \\ College Station, Texas 77843-4221 \\ Phone: 979-458-3393 \\ Fax: 979-845-9641 \\ E-Mail: mhitt@mays.tamu.edu \\ * Corresponding author
}

Acknowledgements: An earlier version of this paper was presented at a symposium, co-organized by the Shanghai Institute for International Studies and the Bush School, Texas A\&M University, held in Shanghai, China, May 26-27, 2005. We thank the discussant, Wang Fenghua for his useful advice. Jay Hartzell, Michael Holmes, Arvind Mahajan, Luis Perez-Batres, Paul Tetlock and Yexiao Xu also provided helpful comments. We thank Alan Montgomery for technical assistance with the software programming. 


\title{
INSIDER TRADING AND THE VALUATION \\ OF INTERNATIONAL STRATEGIC ALLIANCES IN EMERGING STOCK MARKETS
}

\begin{abstract}
$\underline{\text { Abstract }}$
Because stock markets in emerging economies are relatively new, under-regulated and often segmented, their responses to public announcements affecting emerging market firms may differ from responses in developed countries' stock markets. We draw upon institutional theory and stakeholder theory to explain the reactions of emerging stock markets to announcements of international strategic alliances (ISAs) between foreign and emerging market firms. We test the hypotheses, using event-study methodology, on China's stock market, examining reactions to ISA announcements by Chinese firms in 1991-2001. Our results show that, similar to developed markets, ISAs create market value for emerging market firms. However, unlike developed markets, insider trading is likely to capture the value of the "good news" when regulations are weak and markets are segmented by ownership.
\end{abstract}

Word count: 123

Key words: insider trading, international strategic alliance, stock market, event study, market valuation, China, emerging economies, market segmentation, emerging market firm. 


\section{INSIDER TRADING AND THE VALUATION}

\section{OF INTERNATIONAL STRATEGIC ALLIANCES ON EMERGING STOCK MARKETS}

\section{INTRODUCTION}

In many countries, there are well-established "rules of the game" (North, 1990: 1) regulating securities trading and institutions. In the United States, for example, the 1934 Securities Exchange Act and the 1968 Williams Act Amendments regulate insider trading, deterring opportunistic behavior by senior managers and other informed investors with superior non-public information about firm value (Meulbroek, 1992). The U.S. Securities Exchange Commission (SEC) has the authority to enforce securities laws, bringing civil charges against individuals and revoking licenses of market professionals found guilty of improprieties.

Regulations against insider trading protect non-insider shareholders and the investing public (Banerjee \& Eckard, 2001). These laws are especially important for the efficient market hypothesis, which argues that even in markets with substantial information asymmetries, share prices fully reflect all relevant information (Fama, 1991). There are three forms of the efficient market hypothesis: strong, semistrong and weak (Baesel \& Stein, 1979; Brealey \& Myers, 1988). ${ }^{1}$ The U.S. securities market, perhaps the world's most efficient and most regulated, is characterized by semi-strong market efficiency (Brealey \& Myers, 1988: 287).

While securities markets are well established in OECD member countries, the "rules of the game" in Asia, Latin America and the former Soviet Union are relatively new and underdeveloped. Governments in emerging economies established securities markets in the 1980s and 1990s, often triggered by the privatization of state owned enterprises, to generate domestic capital, encourage local entrepreneurship, and assist in privatization. However, the development of strong regulatory institutions has lagged behind the growth of these markets (Hanousek \& Podpiera, 2002). Scholars have stressed the importance of regulatory institutions for market efficiency, namely formal legal shareholder protection (LaPorta, Lopezde-Silanes, Shleifer \& Vishny, 1997; 1998) and law enforcement for securities market development in 
emerging economies (Johnson, LaPorta, Lopez-de-Silanes \& Shleifer, 2000). For example, while insider trading laws exist in 87 of the 103 countries with stock markets, they are enforced in only 38 of them (Bhattacharya \& Daouk, forthcoming). This suggests that emerging stock markets should be characterized as weakly efficient, or at best, in the bottom range of the semi-strong version of the efficient market hypothesis.

Market efficiency is critical to examine the effects of corporate announcements on shareholder value, which normally is done using event study methodology (MacKinlay, 1997; McWilliams \& Siegel, 1997; McWilliams, Siegel \& Teoh, 1999; Miller, 1999). A review of the literature reveals a general paucity of event studies analyzing emerging stock markets. One might expect such paucity of research because the stock markets are relatively new. Databases and software programs are also scarce. ${ }^{2}$ A key factor, however, is that emerging stock markets tend to be thinly traded and institutionally weak, which creates problems for event-study methodology. A major problem is that the stock market may not react to an announcement date because insiders capture the market valuation before the public announcement. Bhattacharya, Daouk, Jorgenson and Kehr (2000: 70), for example, found that the Mexican stock market did not react to corporate news, arguing that information leakages caused "prices to fully incorporate the information before its public release", thus turning an event into a non-event. For these reasons, work on emerging stock markets is in its infancy, and our understanding of how weak regulatory institutions affect market behavior is incomplete.

This paper adds to the literature on the (in)efficiency of emerging stock markets by investigating the market reaction to announcements of a specific strategic action by emerging market firms; that is, the formation of an international strategic alliance (ISA) between a foreign firm and an emerging market firm (EMF). The announcement of a domestic strategic alliance between two local firms is normally treated as "good news" by stock markets. The potential synergies of such an alliance enhance the market valuation of both alliance partners (Das, Sen \& Sengupta, 1998). ISAs between a domestic and foreign partner offer not only synergy benefits but also growth opportunities by exploiting new markets; thus, ISAs should also be positively valued by the market. While the results are somewhat mixed $^{3}$, the general consensus from 
the research is that international strategic alliances create value for developed market shareholders.

Prior event studies on ISAs have been conducted only in established OECD countries' stock markets. No studies have examined the impact of international strategic alliances on the market valuation of emerging market firms; that is, how an ISA announcement affects the market valuation of the EMF's tradable shares on its home country stock market. There have been a few event studies of Chinese-foreign ISAs, for example, but they focus on valuation of the developed market partner (see, for example, Chen, Hu \& Shieh, 1991; Hu, Chen \& Shieh, 1992; Meschi, 2004). ${ }^{4}$ Thus, a fundamental question remains. Does an international strategic alliance offer synergies and growth options that benefit shareholders in emerging stock markets?

To answer this research question, we draw upon institutional theory and the stakeholder literature to explain stock price movements associated with the disclosure of new public information, in our case, the announcement of an ISA involving a foreign firm and an emerging market firm. We build hypotheses predicting how weak institutions and other inefficiencies affect the emerging stock market's reaction to the ISA announcement. Building on Bhattacharya, et al. (2000), we focus on two variables that can cause inefficiency in securities markets: the level of regulatory supervision of the market and the degree of market segmentation. The lower the regulatory supervision and the greater the market segmentation, the higher the probability of knowledge leakages and the more likely that insider trading captures the "good news rents" prior to the public announcement.

We test our hypotheses using event-study methodology to examine the market response to announcements of ISAs by Chinese firms listed on China's two stock exchanges (Shanghai and Shenzhen) over the 1991-2001 period. We search for evidence of information leakages, which suggest insider trading, by considering the traditional "event window" surrounding an announcement, as well as the "pre-announcement" and "post-announcement" periods.

China is a good case study for our analysis. While some scholars contend that China's stock market may be developing better than other transition economies (e.g., Pistor \& Xu, 2004a; 2004b), most scholars and market experts argue that the market continues to suffer from institutional weaknesses. 
Questionable accounting practices, poor corporate governance, insufficient transparency and inadequate supervision have caused excessive market volatility, corrupt practices and insider trading $(\mathrm{Mu}, 2005$; Time Asia Magazine, 2005; Wang \& Xu, 2004).

The regulatory environment in China tightened significantly with the introduction of the 1999 Securities Law and China's joining the World Trade Organization in 2000. We can therefore explore the effects of an improvement in regulatory institutions on insider trading. We test our hypotheses for the full period (1991-2001) and two sub-periods, 1991-1998 (weak regulation) and 1999-2001 (stronger regulation) to determine whether less information leakage occurred in the more recent time period.

China's stock market is also segmented by ownership, a second potential source of market inefficiency (Bhattacharya et al., 2000). Roughly two-thirds of state and corporate (legal entity) shares on the Shanghai and Shenzhen stock exchanges are non-tradable (CSRC, 2004). "Free float" is the ratio of tradable to non-tradable shares of a firm; thus, the average free float in China is one-third, significantly below free float levels in OECD stock markets. In addition to market segmentation concerns, low levels of free float may cause governance problems. Scholars have suggested that non-government shareholders are expected to exercise their rights more freely (Wang \& Xu, 2004), whereas government ownership of company shares may exacerbate corporate governance concerns and stock market quality (Tong, 2004). By comparing the market reaction to ISAs involving firms with higher and lower free float, we explore how market segmentation affects information leakages.

Our paper contributes to the international strategy literature by examining market valuation of international strategic alliances for the emerging market partner. Understanding the behavior of emerging market investors with respect to how stock prices changes related to ISA announcements is important for strategy scholars interested in international institutional environments. We contribute to the stakeholder literature by exploring the implications of differences in corporate governance of emerging market firms for their market valuation. In addition, our paper contributes to the international finance literature on efficiency of securities markets in emerging economies. 


\section{THEORY DEVELOPMENT}

Strategic alliances represent a popular vehicle through which to enter an international market (Hitt et al., 2000). ISAs are cooperative arrangements involving autonomous firms from different countries. They allow partners to share risk and resources, accumulate knowledge, and secure access to the foreign markets. Stock market announcements of an ISA are typically seen as "good news", with positive market valuations around the announcement date.

Stock market reactions to ISA announcements involving both developed and emerging market partner firms have been the subject of several empirical studies. For example, Chen, $\mathrm{Hu}$, and Shieh (1991) found that the U.S. stock market reacted positively to the announcement of Chinese-U.S. ISAs, but the positive wealth effect was negatively related to the size of the foreign investment. $\mathrm{Hu}$, Chen and Shieh (1992), in a follow-up study, found that the market valuation of U.S. firms was positive when the US firms were not already heavily internationalized. Cheng, Fung and Lam (1998) found that announcements of Chinese-U.S. ISAs increased the U.S. firms' market valuation. Most recently, Meschi (2004) found that French firms benefited from the announcement of alliances with Chinese partners, where the size of the wealth effect depended on the French firms' managerial and geographic experience. Hanvanich, Miller, Richards and Cavusgil (2003) found a positive impact on shareholder value for firms with international joint ventures. Other studies finding a positive change in shareholder value associated with equity joint venture (JV) announcements include Koh and Venkatraman (1991), McConnell and Nantell (1985), Merchant and Schendel (2000), and Reuer and Koza (2000).

Looking across these event studies, market reaction to ISA announcements appears to be positive.

These studies, however, focused on the impact of ISAs on the market valuation of developed market firms, as measured in developed stock markets. Should we expect the same positive market reaction to ISA announcements for emerging market firms? We argue, yes, emerging market firms should also benefit from international strategic alliances, and the announcement of ISAs on emerging stock markets should normally be seen as "good news" by investors.

Our reasoning is straightforward, building on the literature on partner selection. Domestic firms 
in emerging markets often partner with foreign investors to acquire resources and to establish relationships. Emerging market firms that have established ties with developed market firms adopt longerterm objectives regarding market position, product markets, and product differentiation strategies (Hooley et al., 1996). Emerging market firms learn knowledge from their partners that can be used in other foreign markets. Given the need for capital, advanced technologies and market access that characterizes emerging market firms (Hitt et al., 2000), an ISA announcement with a foreign partner, especially one from a developed market, should be considered "good news" and positively valued on the EMF's home stock market. Thus, one would normally expect positive overall market returns to ISA announcements. Our first, baseline hypothesis is therefore:

H1 ("good news"): In emerging stock markets, the public announcement of an international strategic alliance will have a positive effect on the market value of an emerging market firm.

The event studies reviewed above were conducted in developed stock markets, with wellestablished rules and institutions that enforce these laws. In emerging markets, however, weak regulatory institutions allow behavior that could be considered illegal in a more regulated environment. We therefore need to take account of the impact of regulatory institutions on market behavior.

One of the underpinnings of institutional theory is that organizations are influenced by "common understandings of what is appropriate and, fundamentally, meaningful behavior" (Zucker, 1983: 105). Institutions include any form of constraint that guides human interactions (North, 1990). Scott (1995: 33) defined institutions as "cognitive, normative, and regulative structures and activities that provide stability and meaning to social behavior". Institutions can include formal written rules as well as informal codes of behavior (North, 1990). Formal rules and informal codes may be violated resulting in punishment. Thus, an important part of the effectiveness of institutions is the cost of monitoring and determining violations, the severity of punishments. In the absence of formal rules, what is considered appropriate and meaningful behavior can become clouded (Newman, 2001; Peng \& Luo, 2000). Illegal behavior in one highly institutionalized environment may be "taken-for-granted" behavior in a less institutionalized environment, especially if the government participates in and therefore implicitly condones the behavior. 
When regulatory institutions are weak, insider trading can become "taken-for-granted" behavior in securities markets. Bhattacharya et al. (2000) concluded that, in emerging economies, stock prices of publicly traded firms did not react to firm-specific announcements. Their empirical test of announcements on the Bolsa Mexican de Valores led Bhattacharya et al. (2000) to support the fourth argument: weak regulation encouraged insider trading such that events became non-events. ${ }^{5}$ Building on these arguments, we hypothesize that information leakages are likely to produce insider trading that captures all the benefits from ISA announcements on emerging stock markets, all other things being equal.

H2 ("insider trading"): When regulatory institutions in emerging stock markets are weak, there is a positive effect on the market value of an emerging market firm before the public announcement of an international strategic alliance.

In addition to the quality of regulatory institutions, stock market efficiency also depends on corporate governance of listed firms. Aoki defined corporate governance as "the structure of rights and responsibilities among the parties with a stake in the firm" (2000: 11). Effective corporate governance has been associated with superior long-term company performance (Gompers, Ishii \& Metrick, 2003). Research on inter-country differences in corporate governance has identified two contrasting governance models: a shareholder-centered model and stakeholder-centered model (Aguilera \& Jackson, 2003; Schneper \& Guillén, 2004). The shareholder-centered model emphasizes the importance of maximizing shareholder value. The firm is evaluated based on cash flow to shareholders, whose interests and objectives are the focal point for managers. The stakeholder-centered model posits that firms are inclined to avoid profit-maximizing risk and expend resources in an attempt to avert destabilizing initiatives such as layoffs (Roe, 2000).

Within this literature stream, one of the fundamental assumptions is established rule of law; however, empirical research has found that rule of law can vary substantially across countries (La Porta et al., 1997; 1998). In countries with a weak rule of law, shareholder rights can be compromised, especially if the government has an ownership stake in publicly traded firms, common in transition economies. In countries with backgrounds in centralized planning, most local managers have been exposed only to state ownership rather than private ownership. These managers are unfamiliar with legitimate authority 
manifested in profit-oriented ownership in market-oriented economies (Steensma \& Lyles, 2000). Even after privatization, high levels of government ownership of formerly state-owned enterprises suggest that the interests of the shareholders may deviate from profit maximization. Government policy objectives such as increasing employment may be important firm objectives. This means that the profit-maximizing goals of outsider shareholders can diverge from those of the government. Therefore, lower levels of government ownership may signal better corporate governance because non-government shareholders may be able to exercise their rights more freely.

Differences in corporate governance can also arise because some listed firms have stronger government ties than others due, in part, to former state-ownership prior to privatization. Shares are given to local residents and/or sold to private buyers, with some percentage held by local and/or national governments. Typically, government shares in formerly state-owned enterprises are non-tradable shares. Thus, corporate governance varies across firms in emerging economies, as reflected by their tradable and non-tradable shares (Wang \& Xu, 2004). The portion of shares deemed tradable, called "free float", has important implications for corporate governance of a listed firm.

The proportion of free float has important implications for market valuation of corporate announcements in emerging stock markets. Market segmentation by ownership provides opportunities for close ties between securities traders and governments to generate profitable opportunities for information leakages. Insider trading is most likely when regulatory institutions are weak. When the EMF has weak corporate governance (i.e., low free float), close ties between insiders and securities traders imply that inside information is more likely to be "cashed in" through insider trading in the pre-announcement period. On the other hand, when an EMF corporate governance is strong (i.e., the firm has high free float), trading in its stock is more similar to trading in a developed stock market. Lower levels of government ownership mean that non-government shareholders can more freely exercise their rights. We therefore expect that "cashing in" on insider information will be limited for high free float EMFs, even when regulatory institutions are weak.

When regulatory institutions are strong, information leakages are deterred and less insider trading 
occur for both high and low free float firms. However, differences between low and high free float EMFs remain, but for a different reason. Emerging market firms with a high percentage of government owned shares (low free float) have less effective corporate governance than high free float EMFs. ISAs with foreign firms, particularly from OECD countries, offer opportunities for transfers of knowledge, financial resources and managerial skills that are in short supply in emerging economies (Hitt et al., 2000). Low free float firms, with their lower quality of corporate governance, should therefore benefit relatively more from the access to resources from ISAs, than should high free float firms. Thus, the market response to an ISA announcement should be greater for low free float EMFs, reflecting the expected gains in their longrun performance after the resource transfer.

However, the resource transfer benefits from an ISA depend on the capacity of the EMF to absorb the resource transfers from the foreign firm through the ISA (Hitt et al., 2000; Brouthers, Brouthers, \& Wilkinson, 1995). For example, low free float firms may have limited capacity to absorb managerial skills of the Western partner. Moreover, one of the sources of conflict and poor performance of ISAs is incongruent goals of the partners. Superior performance is important to Western firms; however, it has not been central to many local firms listed in emerging economy stock markets, most of which are former state-owned enterprises (Tong, 2004) with limited experience in maximizing profitability (Steensma \& Lyles, 2000). Therefore, the foreign and EMF partners may have diverging goals: the foreign partner focuses on superior performance of the ISA, while the EMF has broader goals depending on the extent of government involvement. If the gap in corporate governance between the ISA partners causes divergent expectations for performance, the stock market's generally positive evaluation of the ISA announcement may be adversely affected. Thus, we expect the market valuation of ISA announcements in emerging stock markets with strong regulation to favor the low free float (inefficient corporate governance) relative to the high free float (efficient corporate governance) EMF. The size of the difference, however, will depend on the market's assessment of the EMF's resource capacity and potential for partner conflict.

The arguments presented suggest that low free float firms will benefit more than high free float firms from ISA announcements, regardless of the strength of regulatory institutions. When regulations are 
weak, the benefits are primarily driven by insider trading; when regulations are stronger, insider trading is reduced but greater advantages of ISAs are obtained by EMFs with weak corporate governance remain.

H3 ("market segmentation"): In emerging stock markets, the positive effect on market value of an emerging market firm around the public announcement of an international strategic alliance is larger for low free float firms than high free float firms.

As emerging economy stock markets mature and regulatory institutions strengthen, the overall quality of the markets are expected to improve. Thus, information leakages and insider trading should diminish. With strong regulations, the wealth gains for an EMF from an international strategic alliance should be positive when announced, as hypothesized in H1. However, stock markets in emerging economies are characterized, at best, by the weak form, or the lower range of the semi-strong form, of the efficient market hypothesis. Thus, the range of regulatory institutions in emerging stock markets is expected to vary from weak to stronger, but not strong. Therefore, we argue that:

H4 ("strong regulations"): When regulatory institutions in emerging stock markets are relatively strong, there is a positive effect on the market value of an emerging market firm following the public announcement of an international strategic alliance.

We illustrate our arguments in Figure 1. When regulatory institutions are strong, ISA announcements are perceived to be "good news" by emerging stock markets, given the EMFs' need for the resources and markets offered by foreign firms; therefore, a positive stock market reaction occurs in the announcement window. When regulatory institutions are weak, however, insider trading in the preannouncement period captures all the benefits so there is no effect, in the announcement window. Ownership restrictions that segment the market also offer opportunities that benefit insiders and market traders linked to insiders. The lower the overall free float in the market, the greater the market inefficiencies, exacerbating the inefficiencies caused by weak regulatory institutions.

Because free float levels vary across firms, we anticipate that high free float firms will have better corporate governance and therefore will be less affected by information leakages than low free float firms. Therefore, when regulatory institutions are weak, the stock market's response in the pre-announcement period will be stronger for low free float emerging market firms than for high free float emerging market firms. Even when regulatory institutions are stronger, we expect market valuation to be higher for low 
compared to high free float firms, other things being equal, because they benefit more from international strategic alliances.

Figure 1 goes about here

\section{CHINA'S STOCK MARKET}

China is a good case for studying how emerging stock markets react to the announcement of international strategic alliances. Foreign firms have been investing in the People's Republic of China (PRC) since the PRC first opened its doors to foreign direct investment (FDI) in 1982. The trickle of FDI in the early 1980s rapidly became a flood in the 1990s, and China is now the single largest destination for FDI of all emerging economies (UNCTAD, 2004). FDI in China typically takes the form of an ISA between a foreign firm and a local firm where the Chinese partner is a state owned enterprise (SOE). The alliance may be an equity joint venture or a contractual alliance; it normally involves manufacturing, R\&D and/or marketing activities performed in China. Announcements of ISAs involving Chinese partner firms are reflected in market valuations of firms listed on China's stock market.

Stock exchanges were established in China in 1990 with the explicit purpose of financing state owned enterprises and improving their performance $(\mathrm{Mu}, 2005)$. The Shanghai Stock Exchange (SHSE) opened its doors in 1990; the Shenzhen Stock Exchange (SZSE) in 1991. Both exchanges are non-profit, self-regulatory legal entities (CSRC, 2004: 51). Almost all companies listed on China's stock market are restructured SOEs. Having a firm's stock listed on an exchange for trading was subject to government approval through a quota system introduced in April 1992. Provincial governments nominated firms for the stock exchange, subject to a quota allocation determined by the central government. Pistor and Wu (2004a) argue the quantity constrained system led to bargaining between the two levels of government that improved the quality of firm listings. Although the quota system ended in 2000, the backlog of listings "de facto governed financial markets until the beginning of 2004" (Pistor \& Wu, 2004a: 29).

China's stock market is segmented by ownership, in two ways (Mu, 2005). First, shares of a firm 
are typically categorized into three types: state shares, legal-entity shares and tradable shares. Each share is entitled to the same cash flow and voting rights, regardless of its type. About one-third of a firm's equity consists of state shares (guojia gu), which are owned by either the local or central government and cannot be listed or publicly traded. Another third consists of legal-entity shares, which are held by domestic legal entities (e.g., banks, SOEs, private domestic firms); these shares can be exchanged but not traded. The prohibition against trading in state and legal entity shares was designed to retain majority ownership in the state owned enterprises for the Chinese government. The remaining shares, called Individual Person (IP) shares (geren $g u$ ), can be publicly issued and traded. The second form of ownership segmentation affects only IP shares, which are divided into two types: A shares and B shares. A shares are ordinary shares available only to Chinese citizens and institutions. B shares were originally intended for foreign investors, but in 2001, domestic investors were also permitted to buy B shares. ${ }^{6}$

The originally designated regulator for China's stock market, the People's Bank of China, was replaced in October 1992, after a securities scandal involving insider trading caused street riots. Two regulatory bodies were established, the Chinese Securities Regulatory Commission (CSRC) and the State Council Securities Committee. They merged in 1998 and the CSRC was given much broader regulatory authority (Mu, 2005; Pistor \& Xu, 2004a). China's first comprehensive legislation regulating the stock exchanges, the Securities Law, was issued in December 1998 and took effect on July 1, 1999 (CSRC, 2004). The law gave CSRC the primary power to regulate China's securities markets, including admission to trading, issuing and implementing regulations, enforcing financial market regulations. China's legislature also toughened the Criminal Law against insider trading, such that persons "using or leaking insider information before its official publication may receive up to 10 years in prison and fines ranging from two to five times profits" (China Online, 1999).

The data presented above suggest that weak regulation of China's stock market existed between 1991 and 1998, and stronger regulation existed from 1999 forward. However, even after 1999, China's stock exchanges remain plagued by excessive trading and volatility. Short sales are prohibited, which has had the effect of limiting the supply of a firm's tradable shares $(\mathrm{Mu}, 2005)$. The prevalence of non- 
tradable shares can lead to insider trading, manipulation of stock market prices or tunneling, which refers to the "transferring of resources out of a company to its controlling shareholder" (Johnson, et al., 2000: 22). Chinese firms with strong governmental influence also tend to have low free float (Wang \& $\mathrm{Xu}$, 2004). Local managers are less familiar with the authority manifested in profit-oriented ownership and therefore are less likely to have effective corporate governance that aligns well with that of foreign partners. Business Week (Miller, 2004: 50) described China's stock market as:

The capital markets have been characterized by repeated booms and busts and regulatory chaos. The markets remain hugely inefficient and often corrupt. China's 1,287 listed companies, traded in Shanghai and Shenzhen, are mostly of dubious quality, trade at artificially steep valuations, and are highly illiquid, with two-thirds of the market tied up in non-tradable state-held shares.

These problems have been recognized by China's regulators (CSRC, 2004), who have attempted to increase the percentage of traded shares, improve the quality of public listings, and tighten security regulations through a variety of regulatory measures. ${ }^{7}$

Additional evidence that China's stock market is a good test of market inefficiency in emerging markets comes from scholarly research on this topic. Recent research has tested the efficient market hypothesis on China's stock market and found evidence of serious problems (Liu, Song \& Romilly, 1997; Groenewold, Tang \& Wu, 2003; Groenewold, Wu, Tang \& Fan, 2004). Groenewold et al. (2003), for example, tested the weak and semi-strong versions of the efficient market hypothesis on the Shanghai and Shenzhen exchanges for the 1992-2001 period. They found deviations from the weak form of market efficiency for B-shares, which are owned by foreign investors. However, their results provide support for the weak form of market efficiency in other market segments - in particular shares owned by domestic investors. Thus, previous researchers have concluded that China's stock market is inefficient.

Thus, China is a good test case for our hypotheses about stock market response to ISA announcements, while simultaneously examining the weak form of market efficiency. Regulations are weak, but improved after 1999, offering a test for weak versus stronger regulation. Moreover, average float levels are low so that market segmentation exacerbates weak regulatory institutions. Lastly, differences between high and low free float firms enable tests for market responsiveness differences 
between these groups, and how those differences are affected by the quality of stock market regulation.

\section{METHODOLOGY}

\section{Dataset}

We test our hypotheses using two datasets: CSMAR (China Stock Market and Accounting Research Database), developed by the Shenzhen GTA Information Technology Ltd), and the SDC Platinum Mergers and Alliances. We obtained daily stock market trades on the Shanghai and Shenzhen stock exchanges and the annual financial statements of China's listed companies from CSMAR for the maximum available time period, 1990 to 2001. SDC Platinum provides information on equity and nonequity alliances from 1988-2004. We limit our analysis to international strategic alliances between PRC firms and firms from other countries.

We use the available data in both CSMAR and SDC Platinum to perform an event study, calculating the cumulative abnormal returns (CARs) for Chinese firms listed on the Shanghai and Shenzhen stock exchanges. The final sample is composed of 213 ISA announcements, ${ }^{8}$ of which 166 were for firms listed on the Shanghai stock exchange and 47 were for firms listed on the Shenzhen stock exchange. Because there were only four announcements involving B-share listings, all of our announcements involve A shares. ${ }^{9}$ Information on ISA announcements by year and by country of the foreign partner is provided in Table 1. Because event studies require the estimation of market models based on historical information before the event date, our sample included ISA announcements from 1991 to 2001 .

Insert Table 1 about here

\section{Event Study Methodology}

An event study captures the stock market's response to an event, such as a company announcement that contains new information (e.g., Brown \& Warner, 1985; Eden, Juarez \& Li, 2005; Fama, Fisher, Jensen \& Roll, 1969; McWilliams \& Siegel, 1997). The change in shareholder value 
attributable to the announcement reflects investors' assessment of its long-term effect on firm performance. Researchers have shown that stock-market responses to announcements provide a reliable indication of long-term performance (Healy, Palepu \& Ruback, 1992) and managerial assessments (Koh \& Venkatraman, 1991).

In our study, the change in shareholder value attributable to the announcement thus reflects investors' assessment of the long-term future performance of the ISAs. This methodology determines the effect of an event on a firm's market value using expected stock returns as a benchmark. That is, we measure the change in shareholder value associated with the event as the difference between the actual stock return and expected stock return, referred to as the abnormal return. The sum of abnormal returns around the announcement day is referred to as the cumulative abnormal return (CAR). The CARs created by the ISA announcements represent the change in shareholder value. See Appendix 1 for more details about calculation of the CARs.

The length of the event window is perhaps the most crucial issue in event study methodology. McWilliams and Siegel's (1997) review of event studies revealed that event windows ranged from 181 days $(-90$ to +90$)$ to 3 days $(-1$ to +1$)$. Empirical research has shown that in general, short event windows typically capture the wealth effect associated with the event (Ryngaert \& Netter, 1990). However, these authors also asserted that the nature of the event under study determines the length of the event window. For instance, if it can be shown, or argued, that information leakages are likely to occur, then the window should include some time prior to the event announcement so that abnormal returns related to the information leakages are captured (McWilliams \& Siegel, 1997).

Therefore, we compute CARs for several periods around the event window. First, we examine CARs during two pre-announcement periods: days -10 to -2 (short window), and days -25 to -2 (long window); these measures will be used to test for evidence of information leakages. Second, we measure CARs in two "post-announcement" periods, based on abnormal returns for days +2 to +10 (short window) and +2 to +25 (long window). Third, we compute measures that cover the pre-announcement and announcement windows, in short $(-10$ to +1 days $)$ and long ( -25 to +1 days $)$ form. These are called 
"unanticipated premia" (Linciano, 2003: 207) and are expected to be positive, reflecting the "good news" effect of the ISA announcement. Lastly, we compute CARs for both short (-10 to +10 days) and long ( -25 to +25 days) windows, as measures of total return, following Chen, Yu and Shieh (1991) and Cheng, Fung \& Lam (1998). The latter two measures are used to test H1.

We also compute the "run-up index" for each of the short and long windows. The run-up index is the ratio of the pre-announcement effect to the unanticipated premia, or CAR $(-x, t) / C A R(-x,+1)$ (Linciano, 2003: 207). We set $\mathrm{x}$ at 10 and 25 and $\mathrm{t}=-2$. The run-up effect is a proxy for informed trading in the pre-announcement period; the higher the run-up index the more the event has been anticipated by insiders. The run-up index is a complementary measure to the pre-announcement effect because the greater the pre-announcement CARs, the more information leakage that occurs. We use both measures as proxies for information leakages and insider trading to test hypotheses 3 and 5 .

Lastly, to test robustness of our findings, we computed abnormal returns and CARs based on a post-announcement estimation period of 125 days (days +26 to +150$)$. Both sets of results are similar so only the pre-announcement market mode results are reported herein; post-announcement market mode results are available on request.

Following Wang and Xu (2004), we measure a firm's corporate governance based on free float, which equals the ratio of a company's shares that are freely available to the investing public divided by its total shares (source: CSMAR database). After ranking the firms by free float, we formed three approximately equal groups of high, medium and low free float firms. We compared the high (38.9\% $64.8 \%)$ versus the low $(2.9 \%-10.2 \%)$ free float firms, as tests of our hypotheses. ${ }^{10}$

\section{RESULTS}

The results presented in Tables 2, 3 and 4 are based on pre-announcement market models that use the Shanghai Composite Index in Panel 1 and the Shenzhen Composite Index in Panel 2. Table 2 provides the event study results for the whole period, 1991-2001. Table 3 shows results for the 1991-1998 (weak regulation) period and Table 4 provides results for 1999-2001 (stronger regulation). 
Insert Tables 2, 3 and 4 about here

We test for $\mathbf{H 1}$ (good news) by examining the CARs around the announcement window, and the unanticipated premia. We test for $\mathbf{H} 2$ (insider trading) by examining the CARs in the period before the announcement date. In the first row of Panel 1 of Table 2, for the Market Composite Index based on the Shanghai Stock Exchange (SHSE), the results indicate that for the total sample, the CARs are $1.51 \%$ for the longer pre-announcement period (-25 to -2 days) and $1.30 \%$ for the shorter pre-announcement period (-10 to -2 days). Both CARs are positive and statistically significant. During the announcement period (-1 to +1 days), the CARs are not statistically different from zero. While we did not develop hypotheses for the post-announcement window, it is interesting to note that the CARs were marginally statistically significant and positive in the short post-announcement period ( +2 to +10 days), but not statistically significant in the long post-announcement window $(+2$ to +25 days). When we repeat the tests using the Market Composite Index for the Shenzhen Stock Exchange (SZSE) in Panel 2, the results are essentially unchanged. When the pre-announcement and announcement windows are combined, as the "unanticipated premia", the overall market valuation to ISA announcements is positive and statistically significant in both Panels 1 (SHSE) and 2 (SZSE), and for both short (-10 to +1 days) and long ( -25 to +1 days) windows. Moreover, when we examine the whole period from pre- to post-announcement, CARs are positive and statistically significant for all firms in Panel 1 for the short window ( -10 to +10 days) and for all firms using the long window (-25 to +25 days) in Panel 2.

Next, we separated the sample according to high and low float firms - our measure of high and low effectiveness in corporate governance. Within the high free float group, the results for the two preannouncement periods in Panel 1 indicate positive and statistically significant CARs $(2.22 \%$ for days -25 to -2 , and $1.71 \%$ for days -10 to -2 , respectively). The CARs during the announcement and postannouncement periods are not statistically significant. The unanticipated premia are positive and statistically significant for both long $(-25$ to +1$)$ and short $(-10$ to +1$)$ windows. However, the CARs for the maximum windows are not statistically significant. Panel 2 shows essentially the same results. Within 
the low free float group, the CARs are positive and statistically significant during both pre-announcement periods $(2.81 \%$ for days -25 to -2 , and $1.80 \%$ for days -10 to -2$)$. CARs during the announcement and post-announcement periods were not statistically significant. The unanticipated premia are positive and large for both long and short windows. Moreover, the CARs over the whole period are large and statistically significant also. Panel 2 shows similar results for the Shenzhen Composite Index.

We next compare the CARs for high free float firms with those of low free float firms. We would find support for $\mathbf{H 3}$ (market segmentation) if the CARs for the high free float firms are less than those of low free float firms, and the difference is statistically significant. We compare CARs for low and high free float firms in the pre-announcement period and the announcement period. We also examine the unanticipated premia, and the CARs over the whole period. Panels 1 and 2 in Table 2 show that, while the pattern of the CARs is as predicted (higher for the low free float firms), the t-statistics comparing the two groups are not statistically significant.

Our theoretical model suggests that regulatory quality of the stock market is an important factor affecting market valuation of ISA announcements in emerging economies. H4 (strong regulation) predicts that stronger regulatory institutions will reduce information leakages. As a result, ISA announcements create market value during the announcement period, rather than in the pre-announcement window. To test this hypothesis, we separated our sample into two periods: 1991-1998 (weak regulation) and 19992001 (stronger regulation), with January 1, 1999 as the dividing line. ${ }^{11}$ Table 3 provides our results for the weak regulatory period, 1991-1998. These results are consistent with those for the total sample period. Table 4 provides our results for the stronger regulatory period, 1999-2001.

A caveat must be added about our results because they are hampered by two factors, one practical, and the other statistical. As our brief history of China's stock market suggests, even in 2001 regulatory institutions, while stronger than in the pre-1999 period, are not strong by OECD standards. Thus, our comparison between weak and strong regulatory institutions is really a matter of degree, of comparing the relatively weak with the relatively strong. Second, we are hampered by the smaller number of observations in the 1999-2001 period, which can affect the statistical significance of our results. 
We first examine the effects of stronger regulations on information leakages, insider trading, and the beneficial effects of an ISA in the announcement window, as predicted in H4. In both Panels 1 and 2 of Table 4 (stronger regulations), the pre-announcement and announcement CARs are not statistically significant. The unanticipated premia also are not statistically significant for either the long $(-25$ to +1 days) or short ( -10 to +1 days $)$ windows. Even over the maximum window ( -25 to +25 days $)$, the CARs for the whole group are not statistically significant.

Next, we examine whether there is a difference in market response to ISA announcements between low and high free float firms during the stronger regulatory period (1999-2001). The results of this analysis are shown in Table 4. As presented in the table, there are statistically significant differences between high and low free float firms, although the individual CARs are generally not statistically significant. In the long pre-announcement period, low free float firms have higher CARs than high free float firms, and the difference is statistically significant. The same is the case for the long postannouncement period and over the long total window $(-25$ to +25 days). However, there are no statistically significant differences between low and high free float EMFs for the announcement window and the unanticipated premia.

In Table 5, we reproduce the pre-announcement CARs and unanticipated premia from Tables 2, 3 and 4, and use these numbers to calculate 'run-up indexes' for each period, by category of firm. High index levels suggest that most of the market valuation occurred in the run-up to the announcement period (Linciano, 2003). The run-up index, along with the pre-announcement CARs, therefore provides evidence of information leakages and possible insider trading. As the table shows, the run-up indexes are close to or greater than 100 percent over the total period 1991-2001, for both the long and short windows. For example, the run-up index for all firms for 1991-2001, using the Shanghai Market Composite, is 1.094 for the long (-25 to -2 days) window and 1.111 for the short (-10 to -2 days) window. The ratios jump to 1.179 and 1.222 for the $1991-1998$ period, but fall to 0.878 and 0.872 for the $1999-2001$ period. These results suggest stronger information leakages and insider trading in the earlier (weak regulation) period. 
Insert Table 5 about here

There are also differences in run-up index levels between high and low free float firms. We hypothesized the low free float firms would have weaker corporate governance and be more susceptible to insider trading. Therefore, we anticipate higher run-up indexes for low free float firms. The results in Table 5 are mixed however. Perhaps the clearest results are for the 1999-2001 period, for which the index is .308 for high compared to 1.293 for low free float firms (SHSE), and .289 for high compared to 1.154 for low free float firms (SZSE); there is a large reduction in the run-up index for high free float firms. Presumably, these results reflect the stronger regulations introduced by the 1999 Securities Law.

In summary, our results provide support for $\mathbf{H 1}$ (good news) and $\mathbf{H} 2$ (insider trading), especially during the 1991-1998 time period. The results provide some conditional support for H3 (market segmentation) in the stronger regulatory environment of 1999-2001. However, we find no support for $\mathbf{H 4}$ (stronger regulations).

\section{DISCUSSION}

Our results strongly suggest that there were information leakages associated with the formation of ISAs, and that the informed traders (e.g., insiders) engaged in transactions based on non-public information. The results for the whole period, and for the 1991-1998 period, both show strong evidence of information leakages prior to ISA announcements. The pre-announcement phenomenon dissipates over time, and eventually disappears based on the results for 1999-2001. The run-up indexes show that information leakages fell between the periods, particularly for high free float firms.

Perhaps, the disappearance of the positive CARs during the pre-announcement period was due to the new regulations established at the end of 1998, and enforceable as of mid-1999. Stronger regulations, with more deterrence, might have caused informed traders to refrain from profiting in the preannouncement period for fear of punishment. If this were the case, we should expect positive CARs during the announcement or post-announcement periods in 1999-2001. However, there are none in the 
announcement period, and the results are mixed in the post-announcement periods. The strongest results, both positive and statistically significant, are for low free float firms in the long window $(+2$ to +25$)$ postannouncement period and over the whole ( -25 to +25 days $)$ windows. Even the unanticipated premia are not significant. While the 1999 CSRC regulations obviously had an impact, they do not provide a full explanation for the difference in trading behavior pre- and post-1999. It is conceivable that our findings during the 1999-2001 period may be due to a small sample size, an explanation raised by Bhattacharya et al., (2000). If this is not the case, and we can rule out the other explanations provided by Bhattacharya et al. (2000), an alternative explanation is necessary.

A plausible alternative explanation for the change in behavior is the nature of the investors' perception of an announcement, which likely evolves over time. For example, a public announcement of an ISA may have been assumed to have a positive effect on the Chinese firm's market value, in which case the informed insiders exploited their information advantage in the pre-announcement period. Part of this "any-news-is-good-news" trading environment can be attributed to the general trend toward increases in Chinese stock prices during the early and mid 1990s. However, in later years, ongoing concerns of transparency, corruption, as well as the decline of the "dot.com" stocks on the U.S. market may have prompted a change in perception of major firm announcements regardless of the type (e.g., formation of a major ISA), thus reducing the announcement effect (even for informed insiders). Such changes would lead to no positive abnormal returns.

The event study methodology controls for recent trends in the stock market, but not for changes in investor behavior. Using prospect theory (Thaler, 1980; Tversky \& Kahneman, 1981; Kanodia, Bushman, \& Dickhaut, 1989), we might expect investors to become more willing to take risks under negative conditions (for example, a bear market). As such, they may be more likely to hold rather than sell their stock, although the stocks are performing poorly in the market. This explanation supports Bhattacharya et al.'s (2000) suggestion that the stock market is information inefficient, implying that stock prices are not related to firm values. Anecdotal evidence supports this perspective. Moreover, the Chinese stock market is considered very risky, which is cause for concern when investors are generally 
risk neutral. Price-earnings ratios of firms listed on the Shanghai and Shenzhen markets dramatically exceed those of Chinese firms listed on the Hong Kong or U.S. exchanges (Lee, 2005). However, it may be too early to draw this conclusion because of the limited number of observations for 1999-2001.

The results of our study suggest that the regulatory changes have likely produced stronger enforcement. However, they remain weak compared to stock markets in most of the industrialized countries, especially the United States and the United Kingdom. Although we found few differences in CARs for Chinese firms with high and with low free float, the prevalence of non-tradable shares remains a key issue for Chinese investors, regulators, and government officials (CSRC, 2004). China's regulators have attempted to increase the percentage of traded shares, improve the quality of public listings, and tighten security regulations (CSRC, 2004). But in doing so, they also realize that reducing institutional uncertainty can produce a double-edged sword: reduced state ownership of firms enhances corporate governance, yet large-scale selling of government shares of stock may place downward pressure on stock prices when individual investor skepticism is high, and thus may keep investors on the sidelines.

Our study suggests several needs for future research. First, we did not find differences in CARs between the high and low free float firms. We impute this outcome to the limited sample size. The power index for the non-significant results ranges from 0.027 to 0.265 , which is relatively low, suggesting that with a larger sample size, researchers may be able to achieve the statistical power to identify differences in CARs between the high and low free float firms. Second, a larger sample might be able to provide more convincing support for insider trading during the pre-announcement periods after 1999. Thus, additional research could determine the extent to which that insider trading has been attenuated by regulatory improvements.

Third, different types of international strategic alliances (e.g., R\&D vs. non-R\&D, large firms vs. small firms, and nationality of the foreign partner) might affect the market valuation of ISAs for emerging economy shareholders. As such, there are opportunities to extend Hitt et al.'s (2000) study by examining the performance implications associated with partner selection by emerging market firms.

Our results have implications for studies that use the event study methodology with samples that 
include firms from countries with weak regulatory institutions. Focusing on only the event window-the traditional practice - may under- or over-report the market's response to an announcement. Our study reveals that the event study methodology can be a useful tool to assess ISA performance if the researcher/practitioner considers both the pre-announcement and the announcement periods. In the present study, we infer from our results that focusing on the market response to only one of the ISA partners - typically, the partner from a country with strong regulatory institutions - can understate ISA performance. Instead, the stock market performance of all ISA partners needs to be evaluated. As our study and Bhattacharya et al.'s (2000) results show, researchers using event studies examining firms from emerging economies need to exercise caution.

Bhattacharya and Daouk's (forthcoming) research revealed that insider trading occurs in over 80 countries, with regulatory enforcement clearly lacking in many countries. Another implication of our study is that stronger institutions deter insiders from capturing the "good news rents" before public investors. There is strong evidence of insider trading in China's stock market before 1999 (see Table 3) but little evidence of insider trading thereafter. Moreover, the run-up indexes decrease between the two periods, particularly for high free float firms. Therefore, our results do provide evidence of "good news" for both regulators of, and investors in, China's stock market.

\section{CONCLUSIONS}

Our study sheds light on the use of the event study methodology in emerging economies. We extend the work of Bhattacharya et al. (2000) by revealing evidence of information leakages during the pre-announcement period as reflected by the positive cumulative abnormal returns, and the absence of an announcement effect during the event window. We examined the market valuation of one type of corporate announcement - an international strategic alliance between a foreign firm and an emerging market firm - from the perspective of the emerging market firm in its domestic stock market. We developed a theoretical framework that drew upon the institutional and stakeholder literatures to explain how weak regulatory institutions and markets segmented by ownership likely reduce market efficiency 
and affect valuation of the international strategic alliance for the emerging market firm. We also build on the ISA literature to explain differences in market response for firms with effective and ineffective corporate governance. We contribute to the ISA literature by showing that the performance of the partners from emerging economies needs to be evaluated to provide a more complete understanding of ISA performance. Despite the market inefficiencies, however, ISAs appear to be "good news" for emerging market firms. 


\section{ENDNOTES}

${ }^{1}$ The strong form argues that information and trading costs are zero so that inside information is already incorporated into securities prices and not useful to a trading strategy. The semi-strong form posits that prices reflect information to the point that marginal benefits of acting on information do not exceed marginal costs. Insiders may profit from the use of non-public information, but once the information is announced to the public, the information will have no further trading value. In the weak form, all available public information is not reflected in stock prices so that well-informed investors, in addition to insiders, can take advantage of other investors.

2 While copious data on a daily and even hourly basis is available for US and European stock markets (e.g., Center for Research in Security Prices (CRSP) at http://gsbwww.uchicago.edu/research/crsp/), there are far fewer comparable statistical databases for emerging economy stock markets. Standard and Poor's produces the Emerging Markets Database (http://www.standardandpoors.com) covering 53 stock markets and more than 2,200 stocks. In terms of China, CSMAR (China Stock Market and Accounting Research), developed by the Shenzhen GTA Information Technology Ltd., provides data, from 1990 to 2002, of daily stock market trades on the Shanghai and Shenzhen stock markets and annual financial statements for China's listed companies.

${ }^{3}$ For example, Fröhls, Keown, McNabb and Martin (1998) argue that the overall wealth impact of announcing an international joint venture is positive, but the size of the impact depends on the domestic firm's investment opportunity set (that is, its other alternatives) and shareholder-management alignment. They find evidence that the opportunity set, but not shareholder-management alignment, strongly affects market valuation of U.S. joint ventures with foreign partners. Joint ventures with emerging economy partners such as China offer U.S. firms "bargain priced growth options" that generate positive and significant abnormal returns; joint ventures involving OECD partners, however, offer "positive but insignificant returns" (Fröhls et al., 1998: 17). Ueng, Kim and Lee (2000) also find positive and significant returns to joint venture announcements involving U.S. partners, with larger returns to U.S. 
firms with high ownership advantages. Contrary to Fröhls et al. (1998), however, they find larger returns to joint ventures with developed rather than emerging economy country partners.

${ }^{4}$ The few event studies that have been done have almost entirely focused on "macro issues" such as evaluating the overall efficiency of the stock market (Aggarwal, Inclan \& Leal, 1999; Gonzalez, Spencer \& Walz, 2003; Kim \& Singal, 2000), co-integration across stock markets (Pagán \& Soydemir, 2001; Fernández-Serrano \& Sosvilla-Rivero, 2003; Pagán \& Soydemir, 2001; Zhu, Lu \& Wang, 2004), and the effects of the Asian currency crisis (Ortiz and Arjona, 2001; Lo \& Chan, 2000).

${ }^{5}$ They examined three other possible explanations also, but found support for insider trading. First, the stock market could be information inefficient, implying stock prices were not related to firm values. Second, there may have been no announcements with "good news" value. Third, publicly available forecasts and newspapers may have contained most of the information in the public announcement so there was no surprise.

${ }^{6}$ For the most part, A-share investors are individual investors, securities firms, and a growing number of institutional investors (Green, 2003). These investors tend to have relative small equity stakes in firms. The B-share market is small relative to the A-share market. B shares traded on the Shanghai Stock Exchange (SHSE) are denominated and trade in US dollars; B shares on the Shenzhen Stock Exchange (SZSE) in Hong Kong dollars. There are also H (Hong Kong) and S (foreign) shares, which are traded on exchanges outside of mainland China (CSRC, 2004).

${ }^{7}$ In 2001, regulators encouraged public sale of state shares in a few SOEs, to raise the percentage of traded shares on the Shanghai Stock Exchange. However, this "triggered panic in the markets" and was halted a few months later (Business Update Daily, 2004). On December 31, 2001, the CSRC issued a notice requiring all A-share firms making initial public offerings or issuing additional shares to have their supplementary audits conducted by international, not domestic, accounting firms. This was designed increase the quality of market information (China Online, 2002). New proposed amendments to the 1999 Security Law are now (as of June 2005) under consideration by the Chinese government (Business Week, 
2005). The proposals give the CSRC more enforcement powers and allow investors to file lawsuits in court and claim compensation. Pistor and Wu (2004a: 24) have argued that CSCR's enforcement activities to date have been "rather timid" and argued that stronger deterrence mechanisms are necessary to improve stock market quality, providing scholarly support for the proposed new regulations. Most recently, the government announced a package whereby state owned enterprises would reduce their holdings of non-tradable shares, together with financial loans from the government to prop up failing brokerage firms, as way to improve the quality of China's stock market (Financial Times, 2005). Whether these measures will be successful remains to be seen.

8 Two events were dropped because they involve firms with much higher free float ratios $(100.00 \%$ and $73.02 \%$ ) than the rest of the sample with the ratio ranging from $2.39 \%$ to $64.77 \%$.

${ }^{9}$ Differences between A and B shares are another form of ownership segmentation of China's stock market and therefore another source of possible inefficiency. Because the number of B shares involving ISAs was so small, we were unable to investigate this effect.

${ }^{10}$ Because the average free float level is about one-third, even a "high" free float firm is relatively "low" by OECD standards. We compared the top and bottom thirds of the free float distribution. We also split the sample in half and compared the top and bottom halves. Comparing the top and bottom thirds increases the spread between the two subgroups but reduces the number of observations. The results were similar in both tests, and we report the 1/3-1/3 comparison here.

11 As a follow-up sensitivity analysis, we tested separating the two periods using three different dates: January 1, 1999; July 1, 1999; and January 1, 2000. The results were consistent, with the exception that the later dates leave fewer observations in the second period, which reduces the statistical significance of the results. We report January 1, 1999, results here. 


\section{Appendix 1}

To estimate the stock market's response to each firm's ISA announcement, we follow Brown and Warner (1985). The day of the ISA announcement is considered the event date, (i.e., day 0 or $t=0$ ). The trading days prior to the announcement are day -1 , day -2 , and so on. The days following the announcement are day +1 , day +2 , and so on. We used ordinary least squares to estimate parameters of the market model during a 125 -day estimation period $(\mathrm{t}=$ day -150 to day -26$)$. That is,

$$
r_{i t}=\alpha_{i}+\beta_{i} r_{m t}+e_{i t}
$$

where $\mathrm{r}_{\mathrm{it}}$ equals firm $i$ 's return on day $\mathrm{t}, \beta_{\mathrm{i}}$ represent the systematic risk, $\mathrm{r}_{\mathrm{mt}}$ is the market return, and $e_{\mathrm{it}}$ is the residual on day $t$.

We use two proxies for the market index, the Shanghai Composite Index and the Shenzhen Composite Index. For each market index, we used the equally-weighted market return to calculate the abnormal returns. To examine the robustness of our findings, we repeated all analyses using the valueweighted market return for abnormal return calculations. Similar results were generated.

A firm's risk-adjusted abnormal return $\left(\mathrm{AR}_{\mathrm{it}}\right)$ on day $t$ is:

$$
A R_{i t}=r_{i t}-\hat{\alpha}_{i}-\hat{\beta}_{i} r_{m t}
$$

where $\mathrm{AR}_{\mathrm{it}}$ is the abnormal return of firm $i$ on day $t$, which reveals the impact of new information about firm $i$ on day $t$. The coefficients (with hats) were determined from each firm's estimation-period regression.

$$
A R_{i t}=r_{i t}-\hat{\alpha}_{i}-\hat{\beta}_{i} r_{m t}
$$

where $\mathrm{AR}_{\mathrm{it}}$ is the abnormal return of firm $i$ on day $t$, which reveals the impact of new information about firm $i$ on day $t$.

In an event study, the null hypothesis is that the mean day $t$ abnormal return (i.e., the average of the abnormal returns generated based on the market model) equals zero. This tests whether there was a significant wealth effect to shareholders associated with the event. The test statistic equals the ratio of the day 0 mean abnormal returns to its estimated standard deviation (based on the standard deviation from the 
estimation period mean abnormal returns):

$$
\overline{A R}_{t} / \hat{S}\left(\overline{A R}_{t}\right)
$$

where A-bar equals

$$
\overline{A R}_{t}=\frac{1}{N_{t}} \sum_{i=1}^{N_{t}} A R_{i, t}
$$

and

$$
\hat{S}\left(\overline{A R}_{t}\right)=\left[\sum_{t=-150}^{t=-26}\left(\overline{A R}_{t}-\overline{\overline{A R}}\right)^{2} /(T-1)\right]^{0.5}
$$

and

$$
\overline{\overline{A R}}=\frac{1}{T} \sum_{t=-150}^{t=-26} \overline{A R}
$$

Some studies use cumulative abnormal returns (CARs). To compute each firm's cumulative abnormal return (CAR) for the announcement period, we begin by standardizing each firm's abnormal returns by its estimated standard deviation $\left(\mathrm{SD}_{\mathrm{it}}\right)$ :

$$
\begin{gathered}
S A R_{i t}=A R_{i t} / S D_{i t} \\
S D_{i t}=\left\{S_{i}^{2}\left[1+1 / T\left(R_{m t}-R_{m}\right)^{2} / \sum_{t=1}^{T}\left(R_{m t}-R_{m}\right)^{2}\right]\right\}^{0.5}
\end{gathered}
$$

where $\mathrm{S}_{\mathrm{i}}{ }^{2}$ is the residual variance from the market model for firm $\mathrm{i}, \mathrm{R}_{\mathrm{m}}$ is the mean return on the market portfolio during the estimation period, and $\mathrm{T}$ equals the number of days in the estimation period (in our case 125 days). It is likely that some firms released their ISA announcements on the previous day before the close of the stock markets or near the close of the stock market on the announcement date (day 0 ). Following (Nayyar, 1995), the event window (i.e., the "announcement period") of $k$ days equals 3 (days 1,0 , and +1 ). We compute each firm's cumulative abnormal return (CAR) for the announcement period. Thus, the cumulative abnormal return (CAR for firm i during the $k$-day event window is:

$$
C A R_{i}=\left(1 / k^{0.5)} \sum_{i=1}^{k} S A R_{i t}\right.
$$


We assume that the CARs are independent and identically distributed (i.i.d.). We convert then to i.i.d. variables by dividing $\mathrm{CAR}_{\mathrm{i}}$ by $[(\mathrm{T}-2) /(\mathrm{T}-4)]^{0.5}$ indicating that the average standardized cumulative abnormal return for a sample of $\mathrm{n}$ firms $\left(\mathrm{ACAR}_{\mathrm{i}}\right)$ :

$$
\overline{C A R}_{t}=A C A R_{t}=(1 / n) x 1 /[(T-2) /(T-4)]^{0.5} \sum_{i=1}^{n} C A R_{i t}
$$

The test statistic used to evaluate if ACAR is significantly different from zero (the expected value and our null hypothesis):

$$
Z=A C A R_{t} \times n^{0.5}
$$

We also examine CARs during two pre-announcement periods: days -10 to -2 (short window), and days -25 to -2 (long window). In the former case, we measure each firm's cumulative abnormal return (CAR) for the pre-announcement period:

$$
C A R_{i}=\sum_{t=-2}^{-10} A R_{i t}
$$

In the latter case, we change the period to reflect the change in time. Similarly, we measure CARs in two "post-announcement" periods, based on abnormal returns for days +2 to +10 (short window) and +2 to +25 (long window). 
Figure 1

Market Reaction to the Announcement of an International Strategic Alliance

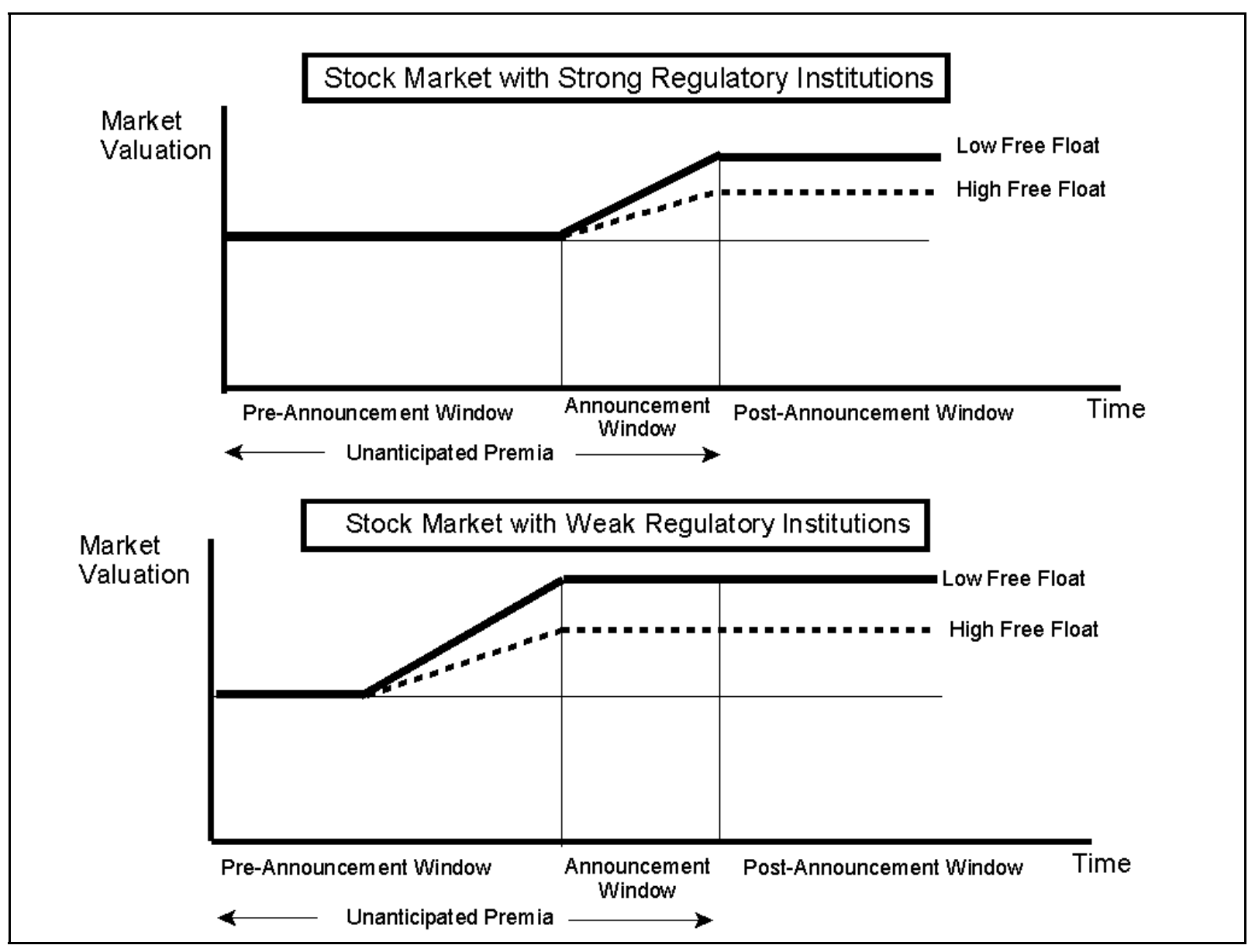


Table 1: ISA Announcements, by Year and Country of the Foreign Partner

Panel 1: Shanghai-Listed Firms

\begin{tabular}{|l|c|c|c|c|c|c|c|c|c|c|c|c|}
\hline & 1991 & 1992 & 1993 & 1994 & 1995 & 1996 & 1997 & 1998 & 1999 & 2000 & 2001 & Total \\
\hline Australia & 0 & 0 & 0 & 1 & 0 & 0 & 0 & 0 & 1 & 1 & 1 & 3 \\
\hline Belgium & 0 & 0 & 0 & 0 & 0 & 0 & 0 & 0 & 1 & 0 & 0 & 1 \\
\hline Brazil & 0 & 0 & 0 & 0 & 0 & 0 & 0 & 0 & 0 & 0 & 1 & 1 \\
\hline Canada & 0 & 0 & 0 & 3 & 0 & 0 & 0 & 0 & 1 & 1 & 1 & 6 \\
\hline Finland & 0 & 0 & 0 & 0 & 0 & 0 & 0 & 0 & 0 & 1 & 0 & 1 \\
\hline France & 0 & 0 & 0 & 0 & 0 & 2 & 1 & 0 & 1 & 1 & 1 & 6 \\
\hline Germany & 0 & 0 & 2 & 4 & 3 & 1 & 2 & 1 & 2 & 0 & 3 & 18 \\
\hline Hong Kong & 1 & 0 & 4 & 1 & 1 & 1 & 0 & 1 & 0 & 1 & 5 & 14 \\
\hline Italy & 0 & 0 & 0 & 0 & 0 & 0 & 0 & 1 & 0 & 1 & 0 & 2 \\
\hline Japan & 0 & 0 & 2 & 5 & 5 & 3 & 1 & 6 & 3 & 2 & 3 & 30 \\
\hline Malaysia & 0 & 0 & 0 & 0 & 0 & 1 & 0 & 0 & 0 & 0 & 0 & 1 \\
\hline Netherlands & 0 & 0 & 0 & 0 & 1 & 0 & 1 & 1 & 0 & 0 & 0 & 3 \\
\hline Saudi Arabia & 0 & 0 & 0 & 0 & 0 & 0 & 1 & 0 & 0 & 0 & 0 & 1 \\
\hline Singapore & 0 & 0 & 0 & 0 & 0 & 0 & 0 & 1 & 1 & 0 & 0 & 2 \\
\hline South Korea & 0 & 0 & 0 & 0 & 0 & 1 & 0 & 1 & 0 & 2 & 3 & 7 \\
\hline Sweden & 0 & 0 & 0 & 0 & 0 & 0 & 0 & 0 & 0 & 1 & 0 & 1 \\
\hline Switzerland & 0 & 0 & 0 & 0 & 0 & 2 & 0 & 0 & 0 & 0 & 0 & 2 \\
\hline Taiwan & 0 & 0 & 0 & 0 & 0 & 0 & 0 & 0 & 0 & 0 & 1 & 1 \\
\hline U.K. & 0 & 0 & 1 & 0 & 1 & 1 & 0 & 1 & 2 & 0 & 2 & 8 \\
\hline U.S. & 0 & 0 & 1 & 6 & 7 & 3 & 6 & 10 & 3 & 9 & 11 & 56 \\
\hline Uganda & 0 & 0 & 0 & 0 & 0 & 0 & 0 & 0 & 0 & 0 & 1 & 1 \\
\hline Viet Nam & 0 & 0 & 0 & 0 & 1 & 1 & 0 & 0 & 0 & 0 & 0 & 2 \\
\hline Totals by year & 1 & 0 & 6 & 23 & 19 & 16 & 12 & 23 & 15 & 20 & 32 & 167 \\
\hline
\end{tabular}

Panel 2: Shenzhen-Listed Firms

\begin{tabular}{|l|c|c|c|c|c|c|c|c|c|c|c|c|}
\hline & 1991 & 1992 & 1993 & 1994 & 1995 & 1996 & 1997 & 1998 & 1999 & 2000 & 2001 & Total \\
\hline Australia & 0 & 0 & 0 & 0 & 0 & 0 & 0 & 0 & 0 & 1 & 1 & 2 \\
\hline Belgium & 0 & 0 & 0 & 0 & 0 & 1 & 0 & 0 & 0 & 0 & 0 & 1 \\
\hline Canada & 0 & 0 & 0 & 0 & 0 & 0 & 0 & 0 & 1 & 0 & 0 & 1 \\
\hline Finland & 0 & 0 & 0 & 0 & 0 & 0 & 0 & 0 & 0 & 0 & 1 & 1 \\
\hline Germany & 0 & 0 & 0 & 0 & 0 & 1 & 0 & 2 & 0 & 0 & 1 & 4 \\
\hline Greece & 0 & 0 & 0 & 0 & 0 & 0 & 0 & 0 & 0 & 0 & 2 & 2 \\
\hline Hong Kong & 0 & 0 & 0 & 0 & 0 & 0 & 1 & 2 & 1 & 0 & 0 & 4 \\
\hline Israel & 0 & 0 & 0 & 0 & 0 & 0 & 0 & 0 & 1 & 0 & 0 & 1 \\
\hline Italy & 0 & 0 & 0 & 0 & 1 & 0 & 0 & 0 & 0 & 0 & 0 & 1 \\
\hline Japan & 0 & 0 & 0 & 0 & 0 & 2 & 0 & 1 & 1 & 0 & 4 & 8 \\
\hline Netherlands & 0 & 0 & 0 & 0 & 0 & 0 & 0 & 1 & 0 & 1 & 0 & 2 \\
\hline Norway & 0 & 0 & 0 & 0 & 0 & 0 & 0 & 1 & 0 & 0 & 0 & 1 \\
\hline Taiwan & 0 & 0 & 0 & 0 & 0 & 0 & 0 & 1 & 0 & 0 & 1 & 2 \\
\hline U.K. & 0 & 0 & 0 & 0 & 0 & 0 & 0 & 2 & 0 & 1 & 0 & 3 \\
\hline U.S. & 0 & 0 & 0 & 1 & 1 & 1 & 2 & 3 & 2 & 3 & 2 & 15 \\
\hline Totals by year & 0 & 0 & 0 & 1 & 2 & 5 & 3 & 13 & 6 & 6 & 12 & 48 \\
\hline
\end{tabular}


Table 2: Cumulative Abnormal Returns, Shanghai and Shenzhen Stock Markets, 1991-2001

Panel 1: Shanghai Composite Index = Market Index

\begin{tabular}{|c|c|c|c|c|c|c|c|c|c|}
\hline & \multicolumn{2}{|c|}{ Pre-announcement } & Announcement & \multicolumn{2}{|c|}{ Post-announcement } & \multicolumn{2}{|c|}{ Unanticipated Premia } & \multicolumn{2}{|c|}{ Whole Period } \\
\hline Group & -25 to -2 & -10 to -2 & -1 to +1 & +2 to +10 & +2 to +25 & -25 to +1 & -10 to +1 & -10 to +10 & -25 to +25 \\
\hline $\begin{array}{l}\text { All Firms } \\
(\mathrm{N}=213)\end{array}$ & $\begin{array}{c}1.51 * * * \\
(3.330)\end{array}$ & $\begin{array}{l}1.30 * * * \\
(4.082)\end{array}$ & $\begin{array}{c}-0.12 \\
(-0.133)\end{array}$ & $\begin{array}{c}0.50+ \\
(1.934)\end{array}$ & $\begin{array}{c}-0.50 \\
(-0.447)\end{array}$ & $\begin{array}{l}1.38 * * \\
(3.091)\end{array}$ & $\begin{array}{c}1.17 * * * \\
(3.463)\end{array}$ & $\begin{array}{c}0.67 * \\
(2.315) \\
\end{array}$ & $\begin{array}{c}-0.88 \\
(-0.435)\end{array}$ \\
\hline $\begin{array}{l}\text { High Free } \\
\text { Float } \\
(\mathrm{N}=64)\end{array}$ & $\begin{array}{c}2.22+ \\
(1.858)\end{array}$ & $\begin{array}{c}1.71 * \\
(2.173)\end{array}$ & $\begin{array}{c}0.10 \\
(0.141)\end{array}$ & $\begin{array}{c}-0.92 \\
(-1.271)\end{array}$ & $\begin{array}{c}-1.54 \\
(-1.564)\end{array}$ & $\begin{array}{c}2.32+ \\
(1.797)\end{array}$ & $\begin{array}{c}1.81+ \\
(1.949)\end{array}$ & $\begin{array}{c}0.88 \\
(0.640)\end{array}$ & $\begin{array}{c}0.78 \\
(0.231)\end{array}$ \\
\hline $\begin{array}{l}\text { Low Free } \\
\text { Float } \\
(\mathrm{N}=64)\end{array}$ & $\begin{array}{l}2.81 * * \\
(2.934)\end{array}$ & $\begin{array}{c}1.80 * * \\
(2.924)\end{array}$ & $\begin{array}{c}0.15 \\
(0.326)\end{array}$ & $\begin{array}{c}0.54 \\
(1.448)\end{array}$ & $\begin{array}{c}0.22 \\
(1.379)\end{array}$ & $\begin{array}{l}2.96 * * \\
(2.872)\end{array}$ & $\begin{array}{c}1.95 * * * \\
(2.691)\end{array}$ & $\begin{array}{c}2.49 * * * \\
(2.981)\end{array}$ & $\begin{array}{l}3.18 * * \\
(3.030)\end{array}$ \\
\hline $\begin{array}{l}\text { High vs. } \\
\text { Low } \\
\text { t-statistic }\end{array}$ & n.s. & n.s. & n.s. & n.s. & n.s. & n.s. & n.s. & n.s. & n.s. \\
\hline
\end{tabular}

Panel 2: Shenzhen Composite Index = Market Index

\begin{tabular}{|c|c|c|c|c|c|c|c|c|c|}
\hline & \multicolumn{2}{|c|}{ Pre-announcement } & Announcement & \multicolumn{2}{|c|}{ Post-announcement } & \multicolumn{2}{|c|}{ Unanticipated Premia } & \multicolumn{2}{|c|}{ Whole Period } \\
\hline Group & -25 to -2 & -10 to -2 & -1 to +1 & +2 to +10 & +2 to +25 & -25 to +1 & -10 to +1 & -10 to +10 & -25 to +25 \\
\hline $\begin{array}{l}\text { All Firms } \\
(\mathrm{N}=209)\end{array}$ & $\begin{array}{c}2.31 * * * \\
(3.420)\end{array}$ & $\begin{array}{c}0.97^{*} \\
\left(2.386^{*}\right)\end{array}$ & $\begin{array}{c}0.09 \\
(0.505)\end{array}$ & $\begin{array}{c}-0.69 \\
(-1.093)\end{array}$ & $\begin{array}{c}-0.60 \\
(-0.474)\end{array}$ & $\begin{array}{c}2.39 * * * \\
(3.391)\end{array}$ & $\begin{array}{c}1.05 * \\
(2.318)\end{array}$ & $\begin{array}{c}0.36 \\
(1.028)\end{array}$ & $\begin{array}{c}1.79 * \\
(2.126)\end{array}$ \\
\hline $\begin{array}{l}\text { High Free } \\
\text { Float } \\
(\mathrm{N}=64)\end{array}$ & $\begin{array}{c}3.02 * \\
(2.159)\end{array}$ & $\begin{array}{c}1.62+ \\
(1.873)\end{array}$ & $\begin{array}{c}0.45 \\
(1.021)\end{array}$ & $\begin{array}{c}-0.74 \\
(-1.139)\end{array}$ & $\begin{array}{c}-0.36 \\
(-1.143)\end{array}$ & $\begin{array}{c}3.47^{*} \\
(2.377)\end{array}$ & $\begin{array}{c}2.07 * \\
(2.133)\end{array}$ & $\begin{array}{c}1.33 \\
(0.865)\end{array}$ & $\begin{array}{c}3.11 \\
(0.942)\end{array}$ \\
\hline $\begin{array}{l}\text { Low Free } \\
\text { Float } \\
(\mathrm{N}=64)\end{array}$ & $\begin{array}{l}5.70 * * * \\
(4.123)\end{array}$ & $\begin{array}{l}2.25 * * \\
(2.856)\end{array}$ & $\begin{array}{c}0.11 \\
(0.479)\end{array}$ & $\begin{array}{c}0.92 \\
(1.525)\end{array}$ & $\begin{array}{c}0.54 \\
(1.405)\end{array}$ & $\begin{array}{c}5.82 * * * \\
(4.041)\end{array}$ & $\begin{array}{c}2.37 * * * \\
(1.709)\end{array}$ & $\begin{array}{l}3.29 * * * \\
(3.044)\end{array}$ & $\begin{array}{c}6.35 * * * \\
(3.891)\end{array}$ \\
\hline $\begin{array}{l}\text { High vs. } \\
\text { Low } \\
\text { t-statistic }\end{array}$ & n.s. & n.s. & n.s. & n.s. & n.s. & n.s. & n.s. & n.s. & n.s. \\
\hline
\end{tabular}

Note: $\mathrm{Z}$ statistics in parentheses, significance based on two-tailed test $(+10 \%, * 5 \%, * * 1 \%, * * * 0.1 \%$ levels, respectively). T-statistics are for differences in CARs for high versus low free-float firms (two-tailed tests, $+10 \%, * 5 \%$ level, n.s. $=$ not significant). 
Table 3: Cumulative Abnormal Returns, Shanghai and Shenzhen Stock Markets, 1991-1998

Panel 1: Shanghai Composite Index = Market Index

\begin{tabular}{|c|c|c|c|c|c|c|c|c|c|}
\hline & \multicolumn{2}{|c|}{ Pre-announcement } & \multirow{2}{*}{$\begin{array}{c}\text { Announcement } \\
-1 \text { to }+1\end{array}$} & \multicolumn{2}{|c|}{ Post-announcement } & \multicolumn{2}{|c|}{ Unanticipated Premia } & \multicolumn{2}{|c|}{ Whole Period } \\
\hline Group & -25 to -2 & -10 to -2 & & +2 to +10 & +2 to +25 & -25 to +1 & -10 to +1 & -10 to +10 & -25 to +25 \\
\hline $\begin{array}{l}\text { All Firms } \\
(\mathrm{N}=122)\end{array}$ & $\begin{array}{c}1.98 * * * \\
(3.784)\end{array}$ & $\begin{array}{l}1.65 * * * \\
(4.786)\end{array}$ & $\begin{array}{c}-0.30 \\
(-0.216)\end{array}$ & $\begin{array}{c}0.02 \\
(0.903)\end{array}$ & $\begin{array}{c}-0.72 \\
(0.102)\end{array}$ & $\begin{array}{c}1.68 * * * \\
(3.487)\end{array}$ & $\begin{array}{l}1.35 * * * \\
(4.024)\end{array}$ & $\begin{array}{l}1.37 * * * \\
(3.631)\end{array}$ & $\begin{array}{l}0.96 * * \\
(2.589)\end{array}$ \\
\hline $\begin{array}{l}\text { High Free } \\
\text { Float }(\mathrm{N}=37)\end{array}$ & $\begin{array}{l}5.01 * * \\
(3.049) \\
\end{array}$ & $\begin{array}{l}2.69 * * \\
(2.730) \\
\end{array}$ & $\begin{array}{c}-0.42 \\
(-0.582) \\
\end{array}$ & $\begin{array}{c}-0.44 \\
(-0.299) \\
\end{array}$ & $\begin{array}{c}-0.15 \\
(-0.297) \\
\end{array}$ & $\begin{array}{l}4.60 * * \\
(2.674) \\
\end{array}$ & $\begin{array}{c}2.27 * \\
(2.063) \\
\end{array}$ & $\begin{array}{c}1.83 \\
(1.366) \\
\end{array}$ & $\begin{array}{c}4.45+ \\
(1.738) \\
\end{array}$ \\
\hline $\begin{array}{l}\text { Low Free } \\
\text { Float }(\mathrm{N}=47)\end{array}$ & $\begin{array}{l}2.74 * * \\
(2.634)\end{array}$ & $\begin{array}{l}2.07 * * \\
(3.280)\end{array}$ & $\begin{array}{c}0.28 \\
(0.653) \\
\end{array}$ & $\begin{array}{c}0.61 \\
(1.183) \\
\end{array}$ & $\begin{array}{c}-0.95 \\
(0.297) \\
\end{array}$ & $\begin{array}{l}3.03 * * \\
(2.699)\end{array}$ & $\begin{array}{c}2.36 * * * \\
(3.164)\end{array}$ & $\begin{array}{c}2.97 * * * \\
(3.163)\end{array}$ & $\begin{array}{c}2.05 * \\
(2.154)\end{array}$ \\
\hline $\begin{array}{l}\text { High vs. Low } \\
\text { t-statistic }\end{array}$ & n.s. & n.s. & n.s. & n.s. & n.s. & n.s. & n.s. & n.s. & n.s \\
\hline
\end{tabular}

Panel 2: Shenzhen Composite Index = Market Index

\begin{tabular}{|c|c|c|c|c|c|c|c|c|c|}
\hline & \multicolumn{2}{|c|}{ Pre-announcement } & Announcement & \multicolumn{2}{|c|}{ Post-announcement } & \multicolumn{2}{|c|}{ Unanticipated Premia } & \multicolumn{2}{|c|}{ Whole Period } \\
\hline Group & -25 to -2 & -10 to -2 & -1 to +1 & +2 to +10 & +2 to +25 & -25 to +1 & -10 to +1 & -10 to +10 & -25 to +25 \\
\hline $\begin{array}{l}\text { All Firms } \\
(\mathrm{N}=119)\end{array}$ & $\begin{array}{c}3.34 * * * \\
(3.828)\end{array}$ & $\begin{array}{c}1.04^{*} \\
(2.464)\end{array}$ & $\begin{array}{c}-0.01 \\
(0.446)\end{array}$ & $\begin{array}{c}-0.34 \\
(0.029) \\
\end{array}$ & $\begin{array}{c}-0.50 \\
(-0.298) \\
\end{array}$ & $\begin{array}{c}3.33 * * * \\
(3.754)\end{array}$ & $\begin{array}{c}1.03 * \\
(2.354)\end{array}$ & $\begin{array}{c}0.69+ \\
(1.796)\end{array}$ & $\begin{array}{c}2.83 * \\
(2.511)\end{array}$ \\
\hline $\begin{array}{l}\text { High Free } \\
\text { Float }(\mathrm{N}=37)\end{array}$ & $\begin{array}{c}6.31 * * * \\
(3.365)\end{array}$ & $\begin{array}{c}2.55^{*} \\
(2.392)\end{array}$ & $\begin{array}{c}0.15 \\
(0.540)\end{array}$ & $\begin{array}{c}-0.23 \\
(-0.250)\end{array}$ & $\begin{array}{c}1.31 \\
(-0.168)\end{array}$ & $\begin{array}{c}6.46^{* * *} \\
(3.351)\end{array}$ & $\begin{array}{c}2.70 * \\
(2.339)\end{array}$ & $\begin{array}{c}2.47 \\
(1.606)\end{array}$ & $\begin{array}{c}7.78 * \\
(2.318)\end{array}$ \\
\hline $\begin{array}{l}\text { Low Free } \\
\text { Float }(\mathrm{N}=47)\end{array}$ & $\begin{array}{c}6.58 * * * \\
(3.959) \\
\end{array}$ & $\begin{array}{l}2.69 * * \\
(3.180)\end{array}$ & $\begin{array}{c}0.20 \\
(0.717) \\
\end{array}$ & $\begin{array}{c}1.09 \\
(1.238) \\
\end{array}$ & $\begin{array}{c}-0.74 \\
(0.166)\end{array}$ & $\begin{array}{c}6.79 * * * \\
(3.967)\end{array}$ & $\begin{array}{c}2.89 * * * \\
(3.109)\end{array}$ & $\begin{array}{l}3.98 * * * \\
(3.157)\end{array}$ & $\begin{array}{l}6.04 * * \\
(2.972)\end{array}$ \\
\hline $\begin{array}{l}\text { High vs. Low } \\
\text { t-statistic }\end{array}$ & n.s. & n.s. & n.s. & n.s. & n.s. & n.s. & n.s. & n.s. & n.s. \\
\hline
\end{tabular}

Note: $\mathrm{Z}$ statistics in parentheses, significance based on two-tailed test $(+10 \%, * 5 \%, * * 1 \%, * * * 0.1 \%$ levels, respectively). T-statistics are for differences in

CARs for high versus low free-float firms (two-tailed tests, $+10 \%, * 5 \%$ level, n.s. $=$ not significant). 
Table 4: Cumulative Abnormal Returns, Shanghai and Shenzhen Stock Markets, 1999-2001

Panel 1: Shanghai Composite Index = Market Index

\begin{tabular}{|c|c|c|c|c|c|c|c|c|c|}
\hline & \multicolumn{2}{|c|}{ Pre-announcement } & \multirow{2}{*}{$\begin{array}{c}\text { Announcement } \\
-1 \text { to }+1\end{array}$} & \multicolumn{2}{|c|}{ Post-announcement } & \multicolumn{2}{|c|}{ Unanticipated Premia } & \multicolumn{2}{|c|}{ Whole Period } \\
\hline Group & -25 to -2 & -10 to -2 & & +2 to +10 & +2 to +25 & -25 to +1 & -10 to +1 & -10 to +10 & -25 to +25 \\
\hline $\begin{array}{l}\text { All Firms } \\
(\mathrm{N}=91)\end{array}$ & $\begin{array}{c}0.86 \\
(0.722) \\
\end{array}$ & $\begin{array}{c}0.82 \\
(0.700) \\
\end{array}$ & $\begin{array}{c}0.12 \\
(0.048)\end{array}$ & $\begin{array}{c}-1.19+ \\
(-1.721)\end{array}$ & $\begin{array}{c}-1.11 \\
(-0.783) \\
\end{array}$ & $\begin{array}{c}0.98 \\
(0.697) \\
\end{array}$ & $\begin{array}{c}0.94 \\
(0.631) \\
\end{array}$ & $\begin{array}{c}-0.26 \\
(-0.662) \\
\end{array}$ & $\begin{array}{c}-0.13 \\
(-0.036) \\
\end{array}$ \\
\hline $\begin{array}{l}\text { High Free } \\
\text { Float }(\mathrm{N}=27)\end{array}$ & $\begin{array}{c}-1.61 \\
(-0.700) \\
\end{array}$ & $\begin{array}{c}0.36 \\
(0.151) \\
\end{array}$ & $\begin{array}{c}0.81 \\
(0.904) \\
\end{array}$ & $\begin{array}{c}-1.59 \\
(-1.599) \\
\end{array}$ & $\begin{array}{c}-3.44^{*} \\
(-2.059) \\
\end{array}$ & $\begin{array}{c}-0.80 \\
(-0.357) \\
\end{array}$ & $\begin{array}{c}1.17 \\
(0.585) \\
\end{array}$ & $\begin{array}{c}-0.41 \\
(-0.610) \\
\end{array}$ & $\begin{array}{c}-4.24+ \\
(-1.673) \\
\end{array}$ \\
\hline $\begin{array}{l}\text { Low Free } \\
\text { Float }(\mathrm{N}=17)\end{array}$ & $\begin{array}{c}3.02 \\
(1.318) \\
\end{array}$ & $\begin{array}{c}1.06 \\
(0.229) \\
\end{array}$ & $\begin{array}{c}-0.27 \\
(-0.450)\end{array}$ & $\begin{array}{c}0.34 \\
(0.843) \\
\end{array}$ & $\begin{array}{c}3.46^{*} \\
(2.183) \\
\end{array}$ & $\begin{array}{c}2.78 \\
(1.092) \\
\end{array}$ & $\begin{array}{c}0.82 \\
(-0.028) \\
\end{array}$ & $\begin{array}{c}1.16 \\
(0.53) \\
\end{array}$ & $\begin{array}{c}6.24^{*} \\
(2.291) \\
\end{array}$ \\
\hline $\begin{array}{l}\text { High vs. Low } \\
\text { t-statistic }\end{array}$ & + & n.s. & n.s. & n.s. & $*$ & n.s. & n.s. & n.s. & $*$ \\
\hline
\end{tabular}

Panel 2: Shenzhen Composite Index = Market Index

\begin{tabular}{|c|c|c|c|c|c|c|c|c|c|}
\hline & \multicolumn{2}{|c|}{ Pre-announcement } & Announcement & \multicolumn{2}{|c|}{ Post-announcement } & \multicolumn{2}{|c|}{ Unanticipated Premia } & \multicolumn{2}{|c|}{ Whole Period } \\
\hline Group & -25 to -2 & -10 to -2 & -1 to +1 & +2 to +10 & +2 to +25 & -25 to +1 & -10 to +1 & -10 to +10 & -25 to +25 \\
\hline $\begin{array}{l}\text { All Firms } \\
(\mathrm{N}=90)\end{array}$ & $\begin{array}{c}0.94 \\
(0.815)\end{array}$ & $\begin{array}{c}0.88 \\
(0.802)\end{array}$ & $\begin{array}{c}0.21 \\
(0.256)\end{array}$ & $\begin{array}{c}-1.16+ \\
(-1.693)\end{array}$ & $\begin{array}{c}-0.72 \\
(-0.381)\end{array}$ & $\begin{array}{c}1.14 \\
(0.854)\end{array}$ & $\begin{array}{c}1.08 \\
(0.822)\end{array}$ & $\begin{array}{c}-0.08 \\
(-0.499)\end{array}$ & $\begin{array}{c}0.42 \\
(0.355)\end{array}$ \\
\hline $\begin{array}{l}\text { High Free } \\
\text { Float }(\mathrm{N}=27)\end{array}$ & $\begin{array}{c}-1.50 \\
(-0.605)\end{array}$ & $\begin{array}{c}0.35 \\
(0.084)\end{array}$ & $\begin{array}{c}0.86 \\
(0.940)\end{array}$ & $\begin{array}{c}-1.44 \\
(-1.455)\end{array}$ & $\begin{array}{c}-2.65 \\
(-1.562)\end{array}$ & $\begin{array}{c}-0.64 \\
(-0.255)\end{array}$ & $\begin{array}{c}1.21 \\
(0.546)\end{array}$ & $\begin{array}{c}-0.23 \\
(-0.544\end{array}$ & $\begin{array}{c}-3.29 \\
(-1.258)\end{array}$ \\
\hline $\begin{array}{l}\text { Low Free } \\
\text { Float }(\mathrm{N}=17)\end{array}$ & $\begin{array}{c}3.27 \\
(1.434) \\
\end{array}$ & $\begin{array}{c}1.05 \\
(0.265)\end{array}$ & $\begin{array}{c}-0.14 \\
(-0.260)\end{array}$ & $\begin{array}{c}0.47 \\
(0.899) \\
\end{array}$ & $\begin{array}{c}4.08 * \\
(2.450)\end{array}$ & $\begin{array}{c}3.13 \\
(1.265) \\
\end{array}$ & $\begin{array}{c}0.91 \\
(0.099)\end{array}$ & $\begin{array}{c}1.38 \\
(0.663)\end{array}$ & $\begin{array}{l}7.21 * * \\
(2.600)\end{array}$ \\
\hline $\begin{array}{l}\text { High vs. Low } \\
\text { t-statistic }\end{array}$ & + & n.s. & n.s. & n.s. & $*$ & n.s. & n.s. & n.s. & $*$ \\
\hline
\end{tabular}

Note: $\mathrm{Z}$ statistics in parentheses, significance based on two-tailed test $(+10 \%, * 5 \%, * * 1 \%, * * * 0.1 \%$ levels, respectively). T-statistics are for differences in

CARs for high versus low free-float firms (two-tailed tests, $+10 \%, * 5 \%$ level, n.s. $=$ not significant). 
Table 5: Unanticipated Premia and Run-up Indexes for China's Stock Market, Various Periods

\begin{tabular}{|c|c|c|c|c|c|c|}
\hline Group & $\begin{array}{c}\text { Long Pre- } \\
\text { announcement }\end{array}$ & $\begin{array}{c}\text { Long Unanticipated } \\
\text { Premia }\end{array}$ & $\begin{array}{c}\text { Long } \\
\text { Run-up Index }\end{array}$ & $\begin{array}{c}\text { Short Pre- } \\
\text { announcement }\end{array}$ & $\begin{array}{c}\text { Short Unanticipated } \\
\text { Premia }\end{array}$ & $\begin{array}{c}\text { Short } \\
\text { Run-up Index }\end{array}$ \\
\hline & -25 to -2 & -25 to +1 & & -10 to -2 & -10 to +1 & \\
\hline \multicolumn{7}{|l|}{ SHSE 1991-2001 } \\
\hline All Firms $(\mathrm{N}=213)$ & $1.51 * * *$ & $1.38 * *$ & 1.094 & $1.30 * * *$ & $1.17 * * *$ & 1.111 \\
\hline High Free Float $(\mathrm{N}=64)$ & $2.22+$ & $2.32+$ & 0.957 & $1.71 *$ & $1.81+$ & 0.945 \\
\hline Low Free Float $(\mathrm{N}=64)$ & $2.81 * *$ & $2.96 * *$ & 0.949 & $1.80 * *$ & $1.95 * * *$ & 0.923 \\
\hline High vs. Low t-statistic & n.s. & n.s. & & n.s. & n.s. & \\
\hline \multicolumn{7}{|l|}{ SZSE 1991-2001 } \\
\hline All Firms $(\mathrm{N}=209)$ & $2.31 * * *$ & $2.39 * * *$ & 0.967 & $0.97 *$ & $1.05^{*}$ & 0.924 \\
\hline High Free Float $(\mathrm{N}=64)$ & $3.02 *$ & $3.47 *$ & 0.870 & $1.62+$ & $2.07 *$ & 0.783 \\
\hline Low Free Float $(\mathrm{N}=64)$ & $5.70 * * *$ & $5.82 * * *$ & 0.979 & $2.25 * *$ & $2.37 * * *$ & 0.949 \\
\hline High vs. Low t-statistic & n.s. & n.s. & & n.s. & n.s. & \\
\hline \multicolumn{7}{|l|}{ SHSE 1991-1998 } \\
\hline All Firms $(\mathrm{N}=122)$ & $1.98 * * *$ & $1.68 * * *$ & 1.179 & $1.65 * * *$ & $1.35 * * *$ & 1.222 \\
\hline High Free Float $N=37$ ) & $5.01 * *$ & $4.60 * *$ & 1.089 & $2.69 * *$ & $2.27 *$ & 1.185 \\
\hline Low Free Float $(\mathrm{N}=47)$ & $2.74 * *$ & $3.03 * *$ & 0.904 & $2.07 * *$ & $2.36 * * *$ & 0.877 \\
\hline High vs. Low t-statistic & n.s. & n.s. & & n.s. & n.s. & \\
\hline \multicolumn{7}{|l|}{ SZSE 1991-1998 } \\
\hline All Firms $(\mathrm{N}=119)$ & $3.34 * * *$ & $3.33 * * *$ & 1.003 & $1.04 *$ & $1.03 *$ & 1.010 \\
\hline High Free Float $(\mathrm{N}=37)$ & $6.31 * * *$ & $6.46 * * *$ & 0.977 & $2.55 *$ & $2.70^{*}$ & 0.944 \\
\hline Low Free Float $(\mathrm{N}=47)$ & $6.58 * * *$ & $6.79 * * *$ & 0.969 & $2.69 * *$ & $2.89 * * *$ & 0.931 \\
\hline High vs. Low t-statistic & n.s. & n.s. & & n.s. & n.s. & \\
\hline \multicolumn{7}{|l|}{ SHSE 1999-2001 } \\
\hline All Firms $(\mathrm{N}=91)$ & 0.86 & 0.98 & 0.878 & 0.82 & 0.94 & 0.872 \\
\hline High Free Float $(\mathrm{N}=27)$ & -1.61 & -0.80 & n.a. & 0.36 & 1.17 & 0.308 \\
\hline Low Free Float $(\mathrm{N}=17)$ & 3.02 & 2.78 & 1.086 & 1.06 & 0.82 & 1.293 \\
\hline High vs. Low t-statistic & + & n.s. & & n.s. & n.s. & \\
\hline \multicolumn{7}{|l|}{ SZSE 1999-2001 } \\
\hline All Firms $(\mathrm{N}=90)$ & 0.94 & 1.14 & 0.825 & 0.88 & 1.08 & 0.815 \\
\hline High Free Float $(\mathrm{N}=27)$ & -1.50 & -0.64 & n.a. & 0.35 & 1.21 & 0.289 \\
\hline Low Free Float $(\mathrm{N}=17)$ & 3.27 & 3.13 & 1.045 & 1.05 & 0.91 & 1.154 \\
\hline High vs. Low t-statistic & + & n.s. & & n.s. & n.s. & \\
\hline
\end{tabular}




\section{References}

Aggarwal, R., Inclan, C. and Leal, R. (1999) 'Volatility in emerging stock markets', Journal of Financial and Quantitative Analysis 34: 33-55.

Aguilera, R. and Jackson, G. (2003) 'The cross-national diversity of corporate governance: Dimensions and determinants', Academy of Management Review 28: 447-465.

Aoki, M. (2000) Information, corporate governance, and institutional diversity: Competitiveness in Japan, the USA, and the transnational economies. Oxford: Oxford University Press.

Baesel, J. and Stein, G. (1979) 'The value of information: Inference from the profitability of insider trading', Journal of Financial and Quantitative Analysis 14: 553-571.

Banerjee, A. and Eckard, E.W. (2001) 'Why regulate insider trading? Evidence from the first great merger wave (1897-1903)', American Economic Review 91: 1329-1349.

Bhattacharya, U. and Daouk, H. (2005) 'The world price of insider trading', Journal of Finance (forthcoming).

Bhattacharya, U., Daouk, H., Jorgenson, B. and Kehr, C-H. (2000) 'When an event is not an event: The curious case of an emerging market', Journal of Financial Economics 55: 69-101.

Brealey, R. and Myers, S. (1988) Principles of corporate finance ( $3^{\text {rd }}$ edition). New York: McGraw-Hill.

Brouthers, K., Brouthers, L. and Wilkinson, T. (1995) 'Strategic alliances: Choose your partners', Long Range Planning 28: 18-25.

Brown, S., and Warner, J. (1985) 'Using daily stock returns: The case of event studies', Journal of Financial Economics 14: 3-31.

Business Update Daily. (2004) 'Fixing stock market's flaws', Financial Times Information. February 2.

Business Week (2005) 'Amended law to protect investors', April 29.

Chen, H., Hu, M.Y. and Shieh, J.C.P. (1991) 'The wealth effect of international joint ventures: the case of US investment in China', Financial Management 20: 31-41.

Cheng, L., Fung, J. and Lam, K. (1998) 'An examination of the determinants of stock price effects of USChinese joint venture announcements', International Business Review 7: 151-161.

China Online (2002) 'CSRC pins hope on foreign accountants', China Online LLC. January 17.

China Securities Regulatory Commission (2004) An Introduction to China's Securities and Futures Markets. April. Available on the Internet at: http://www.csrc.gov.cn/en/jsp/detail.jsp?infoid=1087886774100\&type=CMS.STD

Das, S., Sen, P.K. and Sengupta, S. (1998) 'Impact of strategic alliances on firm valuation', Academy of Management Journal 41: 27-41.

Eden, L., Juarez, L. and Li, D. (2005) 'Talk softly but carry a big stick: Transfer pricing penalties and the market valuation of Japanese multinational in the United States', Journal of International Business Studies 36: 398-414.

Fama, E. (1991) 'Efficient capital markets: II', Journal of Finance 46: 1575-1617.

Fama, E., Fisher, L., Jensen, M. and Roll, R. (1969) 'The adjustment of stock prices to new information', International Economic Review 1: 1-21.

Fernández-Serrano, J. and Sosvilla-Rivero, S. (2003) 'Modeling the linkages between U.S. and Latin American stock markets', Applied Economics 35: 1423-1434.

Financial Times (2005) 'China adds big names to stock market reform plan', June 20.

Fröhls, M., Keown, A., McNabb, M. and Martin, J. (1998) 'Growth opportunities, corporate governance and the market valuation of multinational joint ventures', Managerial and Decision Economics 19: 13-29.

Gompers, P., Ishii, J. and Metrick, A. (2003) 'Corporate governance equity prices', Quarterly Journal of Economics 118: 107-155.

Gonzalez, J.G., Spencer, R.W. and Walz, D.T. (2003) 'A contemporary analysis of Mexican stock market volatility', Applied Financial Economics 13: 741-745.

Green, S. (2003) China's stock market. London: The Economist Newspaper Ltd.

Groenewold, N., Tang, S.H.K. and Wu, Y. (2003) 'The efficiency of the Chinese stock market and the 
role of the banks', Journal of Asian Economics 14: 593-609.

Groenewold, N., Wu, Y., Tang, S.H.K. and Fan, X.M. (2004) The Chinese Stock Market: Efficiency, Predictability and Profitability. Cheltenham, UK: Edward Elgar Publishing.

Hanvanich, S., Miller, S.R., Richards, M. and Cavusgil, S.T. (2003) 'An event study of the effects of partner and location cultural differences in joint ventures', International Business Review 12: 1-16.

Hanousek, J. and Podpiera, R. (2002) 'Information-driven trading at the Prague stock exchange', Economics of Transition 10: 747-759.

Healy, P., Palepu, K. and Ruback, R. (1992) 'Does corporate performance improve after mergers?', Journal of Financial Economics 31: 135-175.

Hitt, M., Dacin, T., Levitas, E., Arregle, J-L and Borza, A. (2000) 'Partner selection in emerging and developed market contexts: Resource-based and organizational learning perspectives', Academy of Management Journal 43: 449-67.

Hooley, G., Cox, T., Shipley, D., Fahy, J. and et al. (1996) 'Foreign direct investment in Hungary: Resource acquisition and domestic competitive advantage', Journal of International Business Studies 27: 683-709.

Hu, M., Chen, H. and Shieh, J. (1992) 'Impact of US-China joint ventures on stockholders' wealth by degree of international involvement', Management International Review 32:135- 148.

Johnson, S., LaPorta, R., Lopez-de-Silanes F, Shleifer A. (2000) 'Tunneling', The American Economic Review 90: 22-27.

Kanodia, C., Bushman, R. and Dickhaut, J. (1989) 'Escalation errors and the sunk cost effect: An explanation based on reputation and information asymmetries', Journal of Accounting Research, 27: 59-77.

Kim, E.H. and Singal, V. (2000) 'Stock market openings: Experience of emerging economies', Journal of Business 73: 25-66.

Koh, J. and Venkatraman, N. (1991) 'Joint venture formations and stock market reactions: An assessment in the formation technology sector', Academy of Management Journal 34: 869-892.

La Porta, R., Lopez-de-Silanes, F., Shleifer, A. and Vishny, R.W. (1997) 'Legal determinants of external finance', Journal of Finance 52: 1131-1150.

La Porta, R., Lopez-de-Silanes, F., Shleifer, A. and Vishny, R.W. (1998) 'Law and finance', Journal of Political Economy 106: 1113-1155.

Lee, D. (2005) 'China stock market misses out on boom', Los Angeles Times. March 7, p. 1.

Linciano, N. (2003) 'The effectiveness of insider trading regulation in Italy: Evidence from stock-price run-ups around announcements of corporate control transactions', European Journal of Law and Economics 16: 199-218.

Lo, W.C. and Chan, W.S. (2000) 'Diagnosing shocks in stock market returns of Greater China', Multinational Finance Journal 4: 269-288.

Liu, X., Song, H. and Romilly, P. (1997) 'Are Chinese stock markets efficient? A cointegration and causality analysis', Applied Economics Letters 4: 511-515.

MacKinlay, A.C. (1997) 'Event studies in economics and finance', Journal of Economic Literature 35: 13-39.

McConnell, J.J. and Nantell, T. (1985) 'Corporate combinations and common stock returns: The case of joint ventures', Journal of Finance 40: 519-536.

McWilliams, A. and Siegel, D. (1997) 'Event studies in management research: Theoretical and empirical issues', Academy of Management Journal 40: 626-57.

McWilliams, A., Siegel, D. and Teoh, S.H. (1999) 'Issues in the use of the event study methodology: A critical analysis of corporate social responsibility studies', Organizational Research Methods 2: 340365.

Merchant, H. and Schendel, D. (2000) 'How do international joint ventures create shareholder value?' Strategic Management Journal 21: 721-737.

Meschi, P-X. (2004) 'Valuation effect of international joint ventures: Does experience matter?' International Business Review 13: 595-612. 
Meulbroek, L. (1992) 'An empirical analysis of illegal insider trading', The Journal of Finance 47: 16611699.

Miller, D. (1999) 'The market reaction to international cross-listings: Evidence from Depository Receipts', Journal of Financial Economics 51: 103-123.

Miller, M. (2004) 'A wild world for funds', Business Week. February 16, p. 50.

$\mathrm{Mu}$, Y. (2005) 'Financial Development in China', Working paper. University of Stirling. Available on the Internet at: http://www.econ.stir.ac.uk/seminars/China-Financial-Development.pdf

Newman, A. (2001) 'Why should anyone be led by you?', Harvard Business Review 79(1): 172.

North, D. (1990) Institutions, institutional change and economic performance. New York: Cambridge University Press.

Ortiz, E. and Arjona, E. (2001) 'Heteroskedastic behavior of the Latin American emerging stock markets', International Review of Financial Analysis 10: 287-305.

Pagán, J.A. and Soydemir, G.A. (2001) 'Response asymmetries in the Latin American equity markets', International Review of Financial Analysis 10: 175-185.

Peng, M. and Luo, Y. (2000) 'Managerial ties and firm performance in a transition economy: The nature of a micro-macro link', Academy of Management Journal 43: 486-501

Pistor, K. and $\mathrm{Xu}, \mathrm{C}$. (2004a) Addressing deterrence and regulatory failure in emerging stock markets. American Law \& Economics Association Annual Meetings. The Berkeley Electronic Press.

Pistor, K. and Xu, C. (2004b) 'Governing stock markets in transition economies: Lessons from China', American Law and Economics Review (Forthcoming).

Reuer, J. and Koza, M. (2000) 'Asymmetric information and joint venture performance: Theory and evidence for domestic and international joint ventures', Strategic Management Journal 21: 81-88.

Roe, M. (2000) 'Political preconditions to separating ownership from corporate control', Stanford Law Review 53: 539-66.

Ryngaert, M. and Netter, J. (1990) 'Shareholder wealth effects of the 1986 Ohio antitakeover law revisited: Its real effects', Journal of Law, Economics, \& Organization 6: 253-262.

Schneper, W.D. and Guillén, M. (2004) 'Stakeholder rights and corporate governance: A cross-national study of hostile takeovers', Administrative Science Quarterly 49: 263-295.

Scott, A. (1995) Institutions and organizations. Thousand Oaks, CA: Sage.

Steensma, H.K. and Lyles, M. (2000) 'Explaining IJV survival in a transitional economy through social exchange and knowledge-based perspectives', Strategic Management Journal 21: 831-851.

Thaler, R. (1980) 'Toward a positive theory of consumer choice', Journal of Economic Behavior and Organization 1: 39-60.

Tong, D. (2004) Current conditions, problems of listed companies and how to exercise regulation: Positioning of the responsibilities of regulatory department and regulatory measures. Center for International Private Enterprise.

Tversky, A. and Kahneman, D. (1981) 'The framing of decisions and the psychology of choice', Science 211: 453-458.

Ueng, C. J., Kim, S. H. and Lee, C. (2000) 'The impact of firm's ownership advantages and economic status of destination country on the wealth effects of international joint ventures', International Review of Financial Analysis 9: 67-76.

UNCTAD (2004) World Investment Report: The Shift Towards Services. Geneva: UNCTAD.

Wang, F. and Xu, Y. (2004) 'What determines Chinese stock returns?', Financial Analysts Journal 60: 65-77.

Zhu, H., Lu, Z. and Wang, S. (2004) 'Causal linkages among Shanghai, Shenzhen, and Hong Kong stock markets', International Journal of Theoretical and Applied Finance 7: 135-149.

Zucker, L. (1983) 'Organizations as institutions', In S. Bacharach (Ed.), Research in the sociology of organizations, 2: 1-47. Greenwich, CT: JAI Press. 